\title{
UWARUNKOWANIA PRAWNE W ZAKRESIE ZASTĘPSTWA PREZYDENTA RZECZYPOSPOLITEJ POLSKIEJ
}

Jedną z fundamentalnych reguł, na których opiera się każdy system konstytucyjny pozostaje troska o zachowanie zasady ciągłości działania konstytucyjnych organów państwa. Potwierdzał to swoim orzecznictwem niejednokrotnie sam Trybunał Konstytucyjny. W sentencji jednego z jego wyroków odnajdujemy takie stwierdzenie: ,polski system konstytucyjny, ukształtowany przez Konstytucję z 1997 r., przyjmuje zasadę ciągłości działania organów konstytucyjnych ze szczególną konsekwencją. Wyeliminowane zostały znane $\mathrm{w}$ innych systemach konstytucyjnych przerwy w działaniu organów konstytucyjnych państwa, jak parlamentarne przerwy międzysesyjne czy przerwy międzykadencyjne, przerwy między dymisją poprzedniego a powołaniem nowego rządu, zastępowanie ministra przez osobę niemającą statusu członka Rady Ministrów". ${ }^{1}$ Uczyniono tak w uznaniu, że wszelkie wyjątki od zasady ciągłości działania organów konstytucyjnych stanowią zagrożenie dla realizacji konstytucyjnych funkcji państwa. Tak też jest w przypadku funkcjonowania polskiej głowy państwa. Wybierany w wyborach powszechnych Prezydent Rzeczypospolitej dostaje od Narodu mandat na ściśle określony czas pięcioletniej kadencji. Wyjątkowo jednak, przy zaistnieniu splotu okoliczności związanych z wprowadzeniem na terytorium państwa jednego ze stanów nadzwyczajnych może on ulec wydłużeniu, choć bardziej prawdopodobnym jest - z racji możliwości zaistnienia faktycznych czy prawnych tego przesłanek - że ów mandat może ulec „,zawieszeniu" lub wygaśnięciu przed terminem wynikającym z kalendarza wyborczego. Stąd zachodzi bezwzględna konieczność konstytucyjnego uregulowania „trybu awaryjnego" pozwalającego na zachowanie niezbędnej decyzyjności w zakresie uprawnień realizowanych przez Prezydenta RP.

Polska tradycja ustrojowa nie zna instytucji wiceprezydenta. ${ }^{2} \mathrm{~W}$ Polsce przedrozbiorowej, w okresie bezkrólewia władzę tymczasowo przejmował jako tzw. inter-

\footnotetext{
1 Za: Sentencja wyroku Trybunału Konstytucyjnego z dnia 23 marca 2006 r. (sygn. Akt K4/06, OTK ZU 2006, seria A, nr 3, poz. 32) ogłoszonej dnia 29 marca 2006 r. (Dz.U. z 2006 r. Nr 51, poz. 377).

2 Również wśród pozostałych państw europejskich jest to wyjątkowo rzadko spotykane rozwiązanie - w zasadzie instytucję wiceprezydenta przyjęła jedynie konstytucja bułgarska. Por.: art. 94, (w:) Konstytucja Bułgarii, War-
} 
rex Prymas Polski. Konstytucje okresu międzywojnia nakazywały z kolei w sytuacji zaistnienia przeszkody w sprawowaniu urzędu głowy państwa lub też jego opróżnienia przejęcie obowiązków prezydenckich przez przewodniczącego izby parlamentu. $^{3}$ Do tradycji tej nawiązywały wszystkie przyjęte w tym zakresie uregulowania konstytucyjne po roku 1989. Nowela konstytucyjna z dnia 7 kwietnia 1989 r., wraz z przywróceniem formuły jednoosobowej głowy państwa, ustanowiła przywilej „zastępstwa” prezydenta po stronie Marszałka Sejmu, ${ }^{4}$ a tzw. Mała Konstytucja z 1992 r. wprowadziła aż dwa rozwiązania awaryjne na wypadek opróżnienia urzędu prezydenta lub zaistnienia przejściowej przeszkody w sprawowaniu przezeń urzędu. Od tej pory, obok Marszałka Sejmu, legitymowanym do przejmowania obowiązków prezydenckich w konstytucyjnie określonych okolicznościach stał się Marszałek Senatu, ${ }^{5}$ a rozwiązanie to zostało przejęte również przez Konstytucję RP z 1997 r. Jej art. 131 ust. 3 stanowi bowiem, że ,jeżeli Marszałek Sejmu nie może wykonywać obowiązków Prezydenta Rzeczypospolitej, obowiązki te przejmuje Marszałek Senatu" ${ }^{6}$ Tym samym obowiązująca ustawa zasadnicza, podobnie jak jej poprzedniczki, hołdując zasadzie zachowania ciągłości działań konstytucyjnych organów państwa stworzyła możliwość szybkiej reakcji na niecodzienne i niejednokrotnie ekstremalne okoliczności, zabezpieczając w ten sposób decyzyjność spraw państwowych. A że są to regulacje, choć rzadko stosowane, to jednak niezbędne, pokazały wydarzenia z dnia 10 kwietnia 2010 r., kiedy to w katastrofie lotniczej zginął prezydent L. Kaczyński wraz innymi dygnitarzami państwa polskiego.

Zasadniczo zgodnie z art. 131 ust. 1-2 Konstytucji RP, należy odróżnić dwie sytuacje owocujące obowiązkiem czasowego przejęcia kompetencji prezydenckich przez uprawniony podmiot. $Z$ jednej strony jest to okoliczność, w której prezydent w czasie trwania swojej kadencji nie może tylko przejściowo sprawować urzędu i wypełniać związanych z nim obowiązków, a z drugiej strony możemy mieć do czynienia z tzw. opróżnieniem urzędu prezydenckiego przed upływem pięcioletniej kadencji lub sytuacją, gdy nie nastąpiło objęcie urzędu przez następcę. Bez względu na charakter przeszkód powodujących niemożność w sprawowaniu funkcji przez urzędującego prezydenta - tymczasowe wykonywanie obowiązków Prezydenta RP będzie obciążać w pierwszej kolejności Marszałka Sejmu lub w jego zastępstwie

szawa 2012, s. 83

$3 \quad$ Konstytucja RP z 17 marca 1921 r. obowiązki te scedowywała na Marszałka Sejmu (por. art. 40 - Dz.U. RP 1921, nr 44, poz. 267), a Konstytucja RP z 23 kwietnia 1935 r. na Marszałka Senatu (por. art. 23 - Dz.U. RP 1935, nr 30, poz. 227). Przepisy Konstytucji marcowej w tym zakresie znalazły dwukrotne zastosowanie w praktyce. Po raz pierwszy marszałek M. Rataj tymczasowo obowiązki głowy państwa zobowiązanym był przejąć na siebie po dokonaniu 16 grudnia 1922 r. udanego zamachu na życie prezydenta G. Narutowicza, a następnie po złożeniu urzędu 15 maja 1926 r. w następstwie przewrotu majowego przez prezydenta S. Wojciechowskiego. Ze względu zaś na krótki okres obowiązywania Konstytucji kwietniowej, szczęśliwie nie zaistniała konieczność ich praktycznego spożytkowania.

$4 \quad$ Por.: art. 32e ust. 1 ustawy z dnia 7 kwietnia 1989 r. o zmianie Konstytucji PRL (Dz.U. z 1989 r. Nr 19, poz. 101).

5 Por.: art. 49 ust. 2 ustawy konstytucyjnej z 17 października 1992 r. o wzajemnych stosunkach miedzy władzą ustawodawczą i wykonawczą Rzeczypospolitej Polskiej oraz o samorządzie terytorialnym (Dz.U. z 1992 r. Nr 84, poz. 426). 
Marszałka Senatu. I jedynie wariant sytuacyjny przesądzi czy będziemy mieli do czynienia z zastępstwem sede plena, tj. gdy fotel prezydenta pozostanie faktycznie obsadzony, ale prezydent tymczasowo nie będzie w stanie go rzeczywiście sprawować, czy też zastępstwem sede vacante, tj. w przypadku opróżnienia urzędu głowy państwa. $^{7}$

Konstytucyjnie określony katalog przesłanek przesądzających o „niemożności definitywnej" ${ }^{8}$ sprawowania urzędu przez prezydenta wymienia następujące okoliczności: 1 - śmierć; 2 - zrzeczenie się urzędu; 3 - stwierdzenie nieważności wyboru prezydenta lub z innych przyczyn nieobjęcia urzędu po wyborze; 4 - uznania przez Zgromadzenie Narodowe trwałej niezdolności prezydenta do sprawowania urzędu ze względu na stan zdrowia; 5 - złożenie go z urzędu prawomocnym orzeczeniem Trybunału Stanu. Stąd w doktrynie można spotkać się z pojęciem ,aktywnego” i „pasywnego" opróżnienia urzędu, ${ }^{9}$ w zależności od tego czy powstała przyczyna miała obiektywnie wpływ na przedterminowe zakończenie kadencji ustępującego prezydenta czy też zaistniała przeszkoda $\mathrm{w}$ objęciu urzędu przez następcę. ${ }^{10} \mathrm{Za}$ każdym razem mamy tu jednak do czynienia z przeszkodą trwałą, która w sposób nieodwracalny uniemożliwia dalsze pełnienie obowiązków osobie prezydenta. W przypadku zaistnienia zaś którejkolwiek z tych okoliczności, ipso iure zostaje powierzone marszałkowi tymczasowe wykonywanie jego obowiązków z mocy samej Konstytucji.

Z kolei na temat przesłanek zaistnienia ,przejściowej niemożności” w wykonywaniu obowiązków przez prezydenta Konstytucja w zasadzie milczy. Jedyną przeszkodę o prawnej naturze sankcjonuje jej art. 145 ust. 3, zgodnie z którym z dniem podjęcia uchwały o postawieniu prezydenta w stan oskarżenia przed Trybunałem Stanu sprawowanie przez niego urzędu ulega zawieszeniu do czasu wydania w sprawie prawomocnego wyroku przez Trybunał Stanu. W praktyce jednak zaistnieć mogą również inne przeszkody, przede wszystkim natury faktycznej o przemijającym charakterze, a rodzące konieczność uruchomienia trybu ,tymczasowego zastępstwa" przez przewodniczącego parlamentu. Mogą one przybrać postać chociażby: choroby przejściowo uniemożliwiającej wypełnianie obowiązków głowy państwa, konieczności leczenia szpitalnego, problemów osobistych lub rodzinnych, niewoli czy nawet zaginięcia prezydenta oraz wielu innych okoliczności faktycznych, któ-

Za: R. Mojak, Prezydent Rzeczypospolitej Polskiej, (w:) W. Skrzydło (red.), Polskie prawo konstytucyjne, Lublin 2003, s. 303; A. Olechno, Prezydent Rzeczypospolitej Polskiej, (w:) M. Grzybowski (red.), Prawo konstytucyjne, Białystok 2008, s. 248

8 Pojęcie zapożyczone od P. Sarneckiego, który posługiwał się określeniami stan „przejściowej niemożności” oraz stan „niemożności definitywnej (trwałej)” dla opisu sytuacyjnego przyjętych rozwiązań ust. 1 i ust. 2 art. 131 Konstytucji RP. Por.: Nota do art. 131, (w:) L. Garlicki (red.), Konstytucja Rzeczypospolitej Polskiej. Komentarz, t. I, Warszawa 1999, s. 3.

9 Za: M. Florczak-Wątor, Konstytucyjne uregulowania problematyki zastępstwa prezydenta w Rzeczypospolitej Polskiej i w państwach sąsiadujących, „Przegląd Prawa Konstytucyjnego” 2010, nr 2-3, s. 187-188.

10 Pierwsze ujęcie odnosi się bowiem do „czynności” zwolnienia urzędu przez osobę dotychczas go sprawującą w sytuacjach konstytucyjnie określonych art. 131 ust. 1-2 oraz ust. 4-5 ustawy zasadniczej; zaś drugie do stanu, w którym urząd głowy państwa nie został obsadzony, gdy jednocześnie nastąpiło jego zwolnienie przez poprzednika. 
rych jednak cechą wspólną zawsze pozostanie przejściowy charakter, mający dawać w założeniu możliwość powrotu do wykonywania swoich konstytucyjnych obowiązków „odsuniętej” osoby prezydenta przed upływem jego kadencji. Oczywiście możliwym jest również z praktycznego punktu widzenia, iż przeszkoda przejściowa przybierze z czasem postać przeszkody o charakterze trwałym. Na przykład, gdy zwieszony $\mathrm{w}$ obowiązkach prezydent $\mathrm{w}$ wyniku postawienia go $\mathrm{w}$ stan oskarżenia przed Trybunałem Stanu zostanie złożony z urzędu prawomocnym jego wyrokiem lub w przypadku zaginięcia osoby prezydenta $\mathrm{z}$ czasem potwierdzony zostanie jego zgon, czego skutkiem prawnym będzie opróżnienie jego urzędu z mocy prawa.

Zgodnie z art. 131 ust. 1 Konstytucji, wiadomym jest tylko, iż dla przejęcia ad interim przez marszałka funkcji prezydenta konieczne jest zaistnienie $\mathrm{z}$ jednej strony czasowej przeszkody w sprawowaniu urzędu głowy państwa oraz z drugiej otrzymanie od samego prezydenta zawiadomienia o zaistnieniu okoliczności uzasadniającej przekazanie przezeń swoich kompetencji na ręce marszałka. W przypadku zaś braku stosownego zawiadomienia, Trybunał Konstytucyjny winien powierzyć mu tymczasowe wykonywanie obowiązków głowy państwa mocą swojego orzeczenia, po uprzednim rozpatrzeniu zasadności wniosku w sprawie samego Marszałka Sejmu. ${ }^{11}$ Oddanie w takich okolicznościach decyzji w ręce Trybunału Konstytucyjnego ma na celu zapobieżenie zaistnienia sytuacji bezpodstawnego, a tym samym i bezprawnego przejęcia przez Marszałka Sejmu co do zasady pełni władzy prezydenckiej. Trybunał Konstytucyjny zgodnie z regułami postępowania sądowego i kierując się przedstawionymi dowodami ma szansę zweryfikować ciąg rzeczywistych zdarzeń mających uzasadnić podjęcie przezeń niezależnej politycznie decyzji. Trybunał działa w tym przypadku nie tyle jako sąd konstytucyjny, co organ zaufania publicznego gwarantujący bezstronne rozstrzygnięcie $\mathrm{w}$ sprawie. ${ }^{12}$ Brak tego rodzaju procedury grozić mógłby bowiem różnego rodzaju nadużyciami, a w skrajnym przypadku nawet ułatwić przeprowadzenie zamachu stanu w państwie.

$\mathrm{Z}$ racji tego, że nie został literą prawa kompleksowo określony charakter przesłanek uniemożliwiających czasowo wypełnianie zadań przez osobę prezydenta, zatem to w jego rękach w pierwszym rzędzie leży dokonanie subiektywnej oceny faktycznej możliwości piastowania swojego urzędu lub jej braku, czego konsekwen-

Funkcję tę Trybunał Konstytucyjny nabył jako swoje nowe uprawnienie w 1997 r. Podobnie do art. 131 ust. 1 Konstytucji RP został wówczas unormowany art. 2 ust. 3 ustawy z dnia 1 sierpnia 1997 r. o Trybunale Konstytucyjnym (Dz.U. z 1997 r. Nr 102, poz. 643 ze zm.), który stanowił, iż „Trybunał na wniosek Marszałka Sejmu rozstrzyga w sprawie stwierdzenia przeszkody w sprawowaniu urzędu przez Prezydenta Rzeczypospolitej, gdy Prezydent nie jest w stanie zawiadomić Marszałka Sejmu o niemożności sprawowania urzędu. W razie uznania przejściowej niemożności sprawowania urzędu przez Prezydenta Trybunał powierza Marszałkowi Sejmu tymczasowe wykonywanie obowiązków Prezydenta Rzeczypospolitej”. Podobnie też czyni obecnie obowiązujący art. 3 ust. 3 pkt 6 uTK z 25 czerwca 2015 r. (Dz.U. z 2015 r., poz. 1064), zgodnie z którym „Trybunał rozstrzyga o stwierdzeniu przeszkody w sprawowaniu urzędu przez Prezydenta RP. W razie uznania przejściowej niemożności sprawowania urzędu przez Prezydenta RP Trybunał powierza Marszałkowi Sejmu tymczasowe wykonywanie obowiązków Prezydenta RP".

12 Tego zdania byli również: Z. Czeszejko-Sochacki, L. Garlicki, J. Trzciński, Komentarz do ustawy o Trybunale Konstytucyjnym, Warszawa 1999, s. 44; czy P. Winczorek, Komentarz do Konstytucji Rzeczypospolitej Polskiej z dnia 2 kwietnia 1997 r., Warszawa 2000, s. 177. 
cją winno być stosowne zawiadomienie o przekazaniu swoich obowiązków uprawnionemu podmiotowi. Rodzi to tym samym ryzyko nadmiernej uznaniowości czy wręcz nadużyć w zakresie delegowania swoich obowiązków przez głowę państwa na podmiot trzeci. ${ }^{13}$ Nie ma bowiem przewidzianej żadnej procedury pozwalającej na zweryfikowanie zasadności prezydenckiego zawiadomienia o zaistnieniu przejściowej niemożności sprawowania urzędu. Brak jest również określenia formy owego zawiadomienia stanowiącego podstawę dającą dopiero możliwość podejmowania niezbędnych działań w zakresie „tymczasowego zastępstwa” głowy państwa. Czy zatem ma ono przybrać formę pisemnego oświadczenia, czy też wystarczającym będzie chociażby ustne powiadomienie? W Stanach Zjednoczonych, pomimo usankcjonowania instytucji wiceprezydenta, utrwaliła się przykładowo praktyka kierowania własnoręcznie napisanego listu w tego typu sytuacji przez urzędującego prezydenta do wiceprezydenta (list kierowany jest również do przewodniczącego Izby Reprezentantów), w którym przekazuje mu pełnię władzy do momentu odzyskania pełnej możliwości sprawowania urzędu. Uczynili tak chociażby prezydenci R. Reagan, czy G. Bush, zanim udali się na zabieg operacyjny wykonywany pod narkozą. Zasadnym wydaje się jednak przyjęcie literą prawa dla prezydenckiego zawiadomienia formy aktu urzędowego, skoro stanowi ono podstawę dla przejęcia obowiązków prezydenckich przez marszałka do czasu ustania przeszkody będącej powodem wszczęcia niniejszej procedury i to najlepiej z zastrzeżeniem wymogu jego kontrasygnowania przez Prezesa Rady Ministrów. W ten sposób mielibyśmy do czynienia przynajmniej z możliwością formalnej weryfikacji przez podmiot zewnętrzny zasadności działań prezydenta w tym zakresie mając na uwadze, że istotą instytucji kontrasygnaty pozostaje scedowanie odpowiedzialności na rząd i jego lidera za podejmowane przez prezydenta kontrasygnowane decyzje. Ale co istotniejsze Konstytucja nie daje też żadnych wskazówek co do czasu trwania czasowej przeszkody w sprawowaniu urzędu prezydenta, dającej Marszałkowi Sejmu uzasadnioną możliwość - w przypadku braku stosownego prezydenckiego zawiadomienia - wnioskowania do Trybunału Konstytucyjnego o stwierdzenie jej zaistnienia i w sukurs temu powierzenia mu wykonywania obowiązków głowy państwa na mocy wyroku Trybunału. Niewykluczoną pozostaje przecież sytuacja, gdy prezydent sądzi, że może sprawować urząd, a Marszałek Sejmu byłby odmiennego zdania. Wówczas na tym tle może pojawić się konflikt. Przykładowo art. 40 Konstytucji RP z 1921 r. wyraźnie stanowił, że jeżeli prezydent przez trzy miesiące nie sprawował faktycznie urzędu, Marszałek Sejmu był prawnie zobowiązanym do niezwłocznego zwołania Sejmu i poddania pod głosowanie wniosku o opróżnienie urzędu głowy państwa. ${ }^{14}$

13 P. Sarnecki wskazuje, iż pomimo że z przyjętego brzmienia uregulowań konstytucyjnych przebija rzeczywista swoboda przypisywania działaniom podejmowanym ewentualnie przez prezydenta $\mathrm{w}$ tym zakresie, to powinny one mieścić się w oczywistych "granicach konstytucji (vide przysięga)". Por.: Nota do art. 131, op. cit., s. 2. tuacji, gdy jego poprzednik nie mógł wykonywać swoich obowiązków przez okres dłuższy niż trzy miesiące. Z kolei Konstytucja Słowacji (art. 105 ust. 2) stanowi, że jeżeli prezydent nie może sprawować swojej funkcji dłużej 
Poza tym Konstytucja nie odnosi się żadną miarą do sytuacji ponownego przejęcia obowiązków przez prezydenta. W końcu przyjmowane przez marszałka zastępstwo ad interim $\mathrm{w}$ zakresie wypełniania obowiązków głowy państwa trwa $\mathrm{z}$ założenia tylko do momentu ustania przeszkody rodzącej niniejszy obowiązek.

Równie problematyczne od praktycznej strony, pomimo ich zasadniczo konkretnego wyliczenia, mogą okazać się przesłanki opróżnienia urzędu głowy państwa lub jego nieobsadzenia, determinujące ex lege przejęcie obowiązków prezydenckich przez Marszałka Sejmu. I tak choć śmierć człowieka jest przesłanką zasadniczo obiektywną, to z prawnego punktu widzenia wymaga potwierdzenia aktem zgonu lub sądowym orzeczeniem o uznaniu za zmarłego w przypadku zaginionej osoby. Te dokumenty co do zasady bowiem wywołują dopiero stosowne implikacje w sferze przejmowanych praw i obowiązków po zmarłej osobie. Zatem czy w praktyce Marszałek Sejmu zobowiązany jest przejąć stosowne obowiązki głowy państwa z chwilą powzięcia wiarygodnej wiadomości o śmierci, czy też dopiero z chwilą formalnego jej potwierdzenia? Pamiętając, że wprowadzenie instytucji „zastępstwa” w sprawowaniu władzy prezydenckiej ma na celu zagwarantowanie, mimo zaistnienia sytuacji nadzwyczajnych, nieprzerwanego, prawidłowego i jak najbardziej efektywnego funkcjonowania mechanizmów państwowych, należy przyjąć założenie, iż nadmierny formalizm w tym względzie mógłby okazać się szkodliwy z punktu widzenia założonych celów i interesów państwa. Odmienne stanowisko prowadziłoby bowiem do kreacji sytuacji, w której przez pewien czas w państwie (liczony nawet w latach, w przypadku konieczności sądowego uznania osoby prezydenta za zmarłą ${ }^{15}$ ) nie mogłoby być osoby prawnie wykonującej obowiązki prezydenta. ${ }^{16} \mathrm{Jak}$ dotychczas w praktyce ustrojowej mieliśmy do czynienia dwukrotnie z przypadkiem śmierci urzędującego prezydenta. Pierwsza tego typu sytuacja miała miejsce jeszcze w początkach odradzającej się Rzeczypospolitej. Po zabójstwie w 1922 r. prezydenta G. Narutowicza Marszałek Sejmu, choć tego samego dnia, to jednak dopiero po doręczeniu wystawionej przez lekarza karty zgonu ogłosił przejęcie obowiązków głowy państwa. Natomiast odmienna sytuacja miała miejsce w 2010 r., kiedy w wyniku katastrofy lotniczej i to na terytorium obcego państwa (tj. Federacji Rosyjskiej) zginął prezydent L. Kaczyński. Wówczas na podstawie korespondencji dyploma-

niż sześć miesięcy (w pierwotnej wersji obowiązywała formuła jednego roku) Rada Narodowa winna go odwołać i dokonać wyboru kolejnej osoby na to stanowisko. Za: Konstytucja Estonii, Warszawa 2000, s. 50; Konstytucja Słowacji, Warszawa 1993, s. 67 oraz http://libr.sejm.gov.pl/tek01/txt/konst/slowacja2011.html (data dostępu: 30.06.2015 r.).

Por.: art. 29 i art. 30 ustawy z dnia 23 kwietnia 1964 Kodeks cywilny (tekst jedn. Dz.U. z 2014 r., poz. 121 ze zm.). Powyższe uregulowania kodeksowe stanowią, iż osoba zaginiona może zostać uznana za zmarłą, jeżeli upłynęło lat 10 od końca roku kalendarzowego, w którym według istniejących informacji jeszcze żyła. Jednak gdyby zaginiony ukończył 70 lat wystarczającym dla uznania go za zmarłego byłby upływ lat 5 . Zaś powyższe terminy ulegają skróceniu, gdyby zaginięcie było wynikiem katastrofy lotniczej, lądowej czy morskiej (po upływie 6 miesięcy od dnia zdarzenia albo po upływie 1 roku od stwierdzenia zaistnienia bezpośredniego niebezpieczeństwa dla życia osoby zaginionej). 16 Choć można spotkać w doktrynie i głosy stawiające na konieczność posiłkowania się urzędowym aktem zgonu.
Zob.: B. Banaszak, Konstytucja Rzeczypospolitej Polskiej. Komentarz, Warszawa 2009, s. 656 . 
tycznej dotyczącej tego tragicznego w skutkach wydarzenia, ówczesny Marszałek Sejmu B. Komorowski przejął wykonywanie obowiązków prezydenckich. ${ }^{17}$ Również zrzeczenie się urzędu przez samego prezydenta determinujące przejęcie jego uprawnień przez marszałka, głównie z racji braku literalnego określenia jego formy prawnej czy też wyraźnego wskazania, do jakiego organu winno być kierowane pozostaje kłopotliwą formułą. Jak dotychczas tylko prezydent S. Wojciechowski w 1926 r. złożył rezygnację z pełnionego stanowiska, czyniąc to na forum Rady Gabinetowej zwołanej w związku wydarzeniami tzw. przewrotu majowego, a następnie przesyłając stosowne oświadczenie o przekazaniu swoich konstytucyjnych uprawnień wraz z uzasadnieniem swojej decyzji ówczesnemu Marszałkowi Sejmu M. Ratajowi. Zapewne i dziś należałoby się spodziewać złożenia stosownego prezydenckiego oświadczenia na ręce marszałka. Choć w literaturze można napotkać również propozycję, iż prezydent winien owego zrzeczenia dokonywać $\mathrm{w}$ formie orędzia przed Zgromadzeniem Narodowym, co stanowić miałoby stosowną antytezę do objęcia przez niego urzędu poprzez złożenie przysięgi na forum tegoż Zgromadzenia. ${ }^{18}$

Z kolei przyznanie Zgromadzeniu Narodowemu uprawnienia o decydowaniu w formie uchwały powziętej większością co najmniej 2/3 głosów ustawowej liczby jego członków o zaistnieniu trwałej niezdolności prezydenta do sprawowania urzędu ze względu na stan zdrowia również rodzi szereg wątpliwości i związanych z tym pytań. Przede wszystkim kto i kiedy miałby prawo inicjować zwołanie Zgromadzenia Narodowego dla rozpatrzenia niniejszej sprawy? Bo choć Konstytucja w art. 114 ust. 2 zastrzega, iż warunki zebrania się Zgromadzenia Narodowego w przypadkach określonych przepisami ustawy zasadniczej regulować ma jego regulamin, to jak dotychczas doczekaliśmy się uregulowania w tej formie przypadku zwołania Zgromadzenia Narodowego jedynie celem złożenia przysięgi przez nowo wybranego prezydenta. ${ }^{19}$ Nie istnieją zaś poza art. 131 ust. 2 pkt 4 Konstytucji żadne bardziej szczegółowe regulacje dotyczące jego procedowania $\mathrm{w}$ interesującym nas zakresie. Oczywistym jest przy tym, że decyzja Zgromadzenia Narodowego w tym przedmiocie winna znajdować swoją podwalinę w stosownej opinii medycznej wydanej przez konsylium lekarskie, bowiem Zgromadzenie Narodowe ze swej natury nie jest predestynowane do oceny, jak poważny jest stan zdrowia prezydenta. Zgromadzenie Narodowe może na jej podstawie jedynie w sposób ostatecznie wiążący oficjalnie potwierdzić istniejący stan rzeczy, tj. że niemożliwym już będzie do końca kadencji wykonywanie obowiązków przez głowę państwa, w przeciwnym razie uchwała Zgromadzenia Narodowego nabierałaby charakteru decyzji o wymiarze po-

17 Za: M. Zubik, Gdy Marszałek Sejmu jest pierwszą osobą w państwie, czyli polskie interregnum, „Przegląd Sejmowy" 2010, nr 5 (100), s. 78.

18 Zob.: G. Pastuszko, Marszałek Sejmu jako osoba wykonująca tymczasowo obowiązki Prezydenta RP - dylematy konstytucyjne, „Przegląd Prawa Konstytucyjnego” 2011, nr 1, s. 98.

19 Por.: Uchwała Zgromadzenia Narodowego z dnia 6 grudnia 2000 r. Regulamin Zgromadzenia Narodowego zwoływanego w celu złożenia przysięgi przez nowo wybranego Prezydenta Rzeczypospolitej Polskiej (M.P. 2000, nr 40, poz. 774). 
litycznym. Ale czy inicjatywa jego zwołania w tym przypadku winna być uprawnieniem Marszałka Sejmu (jak w przypadku zaprzysiężenia prezydenta-elekta, zgodnie $\mathrm{z}$ art. 1 reg. Zgromadzenia Narodowego)? W końcu pozytywne skonstatowanie przez Zgromadzenie Narodowe zaistnienia trwałej niezdolności w wykonywaniu obowiązków po stronie prezydenta skutkuje opróżnieniem jego urzędu i przekazaniem z mocy prawa ich wykonawstwa właśnie w pierwszej kolejności na ręce Marszałka Sejmu, który tym sposobem staje się czasowo „pierwszą osobą w państwie". Może w tym przypadku regulamin Zgromadzenia Narodowego, wyjątkowo, pierwszeństwo w zwoływaniu tego gremium „odstąpiłby” Marszałkowi Senatu. Poza tym, również i w tym przypadku nie zostały określone co oczywiste rodzajowo schorzenia mogące skutkować niemożnością sprawowania władzy ani żadne terminy, których upływ warunkowałby ewentualnie poddanie pod osąd Zgromadzenia Narodowego powstałej sytuacji, przejawiającej się przykładowo długotrwałym zaniechaniem jakichkolwiek działań przez głowę państwa. Zdaniem niektórych przedstawicieli doktryny „brak klarownie określonych ram czasowych daje parlamentarzystom sposobność podjęcia decyzji arbitralnej i w efekcie obarczonej ryzykiem zastosowania politycznej reperkusji w stosunku do pałacu prezydenckiego." ${ }^{20}$ Poza tym, kto i pod jakimi warunkami miałby prawo zwracać się o sporządzenie opinii medycznej oceniającej stan zdrowia urzędującego prezydenta? W końcu żadne przepisy nie nakładają obowiązku regularnego poddawania się takim ocenom medycznym urzędującego prezydenta. Jak z tego należy przypuszczać, brak szczegółowych regulacji proceduralnych $w$ tym zakresie może skutkować tym, iż pomimo zaistnienia w praktyce definitywnej niemożności wykonywania konstytucyjnych obowiązków przez urzędującego prezydenta, trudnym okazać się może z prawnego punktu widzenia doprowadzenie do przyjęcia uchwały przez Zgromadzenie Narodowe, dającej dopiero faktyczną możliwość przejęcia kompetencji prezydenckich przez Marszałka Sejmu, a tym samym zachowania ciągłej decyzyjności w istotnej części spraw państwowych.

Najmniej problematyczną z wymienionych $\mathrm{w}$ art. 131 ust. 2 Konstytucji jest sytuacja złożenia głowy państwa z urzędu prawomocnym orzeczeniem Trybunału Stanu. Oczywiście podjęcie przez Zgromadzenie Narodowe decyzji o postawieniu urzędującego prezydenta w stan oskarżenia przed Trybunałem Stanu czy to za dopuszczenie się deliktu konstytucyjnego, czy przestępstwa rodzi sytuację długoterminowej niemożności wykonywania przezeń obowiązków, ale tu Konstytucja już w miarę w pełnym wymiarze zabezpiecza ciągłość działań tego urzędu. Zastępstwo prezydenta przez Marszałka Sejmu w tym przypadku na dobrą sprawę bowiem z formalnego punktu widzenia następuje o wiele wcześniej. Zgodnie z art. 145 ust. 3 Konstytucji, podjęcie uchwały w tym przedmiocie przez Zgromadzenie Narodowe przynosi „skutek uboczny” w postaci zawieszenia urzędującego prezydenta w jego 
obowiązkach. Mamy więc do czynienia z pojawieniem się ewidentnej tymczasowej przeszkody, która do czasu podjęcia ostatecznego rozstrzygnięcia w sprawie przez Trybunał Stanu uniemożliwia zgodnie z literą prawa wypełnianie przez prezydenta jego obowiązków i tym samym skutkuje koniecznością ich scedowania na Marszałka Sejmu (poprzez zawiadomienie lub w przypadku jego braku, na podstawie orzeczenia Trybunału Konstytucyjnego). Prawomocne orzeczenie Trybunału Stanu w tym przypadku może jedynie zmienić to, że dotychczasowe zastępstwo ad interim ustanie w sytuacji, gdy Trybunał Stanu wyda orzeczenie uniewinniające go od stawianych zarzutów albo przekształci się w konieczność dalszego sprawowania funkcji prezydenckich przez marszałka, ale już w sytuacji opróżnienia jego urzędu (a to pociąga za sobą również konieczność zarządzenia przez Marszałka Sejmu, zgodnie z rygorem art. 128 ust. 2 Konstytucji, przedterminowych wyborów prezydenckich). Mało komfortowym w praktyce jedynie może okazać się wielomiesięczny okres zastępstwa ad interim Prezydenta RP, bowiem ani prace parlamentarne w zakresie pociągania do odpowiedzialności konstytucyjnej wysokich funkcjonariuszy państwa, ani tym bardziej postępowanie sądowe przed Trybunałem Stanu nie są przez prawo limitowane czasowo. ${ }^{21}$ Podobną sytuację wielomiesięcznego zastępstwa sede vacante będziemy mieli w sytuacji stwierdzenia przez Sąd Najwyższy nieważności przeprowadzonych wyborów na urząd prezydenta czy nieobjęcia przez następcę ustępującego prezydenta urzędu z innych przyczyn. A zaistnienie tej ostatniej sytuacji może mieć miejsce chociażby, gdy nie dojdzie do złożenia wobec Zgromadzenia Narodowego przysięgi przez prezydenta-elekta lub też nowo wybrana głowa państwa choć złoży przysięgę, to jednak niezgodną z brzmieniem roty konstytucyjnej określonym art. 130 ustawy zasadniczej.

Dodatkowo warto wspomnieć, iż najbardziej zauważalna przez doktrynę luka prawna kryje się przede wszystkim w samym sformułowaniu art. 131 ust. 2 Konstytucji RP, zgodnie z którym Marszałek Sejmu jedynie ,,do czasu wyboru” nowej głowy państwa wykonuje obowiązki prezydenckie w przypadku opróżnienia urzędu lub zaistnienia przeszkody w jego objęciu. Mamy tutaj do czynienia z sytuacją, w której ,,norma prawna jest niewatpliwa, a jedynie wynik interpretacji jest nieakceptowany". ${ }^{22}$ Ustrojodawca zdecydowanie bowiem w kontekście zagwarantowania ciągłości działania urzędu Prezydenta RP wadliwie określił ramy czasowe sprawowania władzy w przypadku zastępstwa sede vacante przez Marszałka Sejmu.

21 Obecnie, na mocy art. 119 ust. 1 oraz art. 120 ust. 1 ustawy z dnia 25 czerwca 2015 r. o Trybunale Konstytucyjnym (Dz.U. z 2015 r., poz. 1064), trybunał działając na wniosek Marszałka Sejmu w przedmiocie stwierdzenia przeszkody w sprawowaniu urzędu przez Prezydenta RP, może powierzyć tymczasowe wykonywanie jego obowiązków na okres nie dłuższy niż 3 miesięcy. Gdyby jednak po upływie tegoż terminu okoliczności, które przejściowo uniemożliwiają prezydentowi sprawowanie urzędu nie ustały, Marszałek Sejmu może powtórnie, ale tylko jednokrotnie, wystąpić do Trybunału z ponownym wnioskiem w sprawie stwierdzenia przeszkody w sprawowaniu urzędu przez głowę państwa.

22 Za: M. Podsiadło, Odporność polskiego ustroju na „sytuacje awaryjne”, (w:) S. Biernat (red.), Konstytucja Rzeczypospolitej Polskiej w pierwszych dekadach XXI wieku wobec wyzwań politycznych, gospodarczych, technologicznych i społecznych, Warszawa 2013, s. 234. 
Sformułowanie konstytucyjne winno bowiem przewidywać konieczność jego sprawowania $w$ tych nadzwyczajnych okolicznościach aż do rzeczywistego objęcia urzędu przez następcę prezydenta, którego kadencja uległa już zakończeniu. Dopiero bowiem objęcie urzędu przez nowo wybranego prezydenta oznaczać będzie przekształcenie go w pełnoprawnie urzędującą głowę państwa, mogącą od tej chwili korzystać z pełni konstytucyjnie przyznanych uprawnień. Wszelkie zaś ewentualne czynności podejmowane przez prezydenta-elekta w charakterze głowy państwa są dotknięte nieważnością, stąd nie mogą wywołać żadnych, choćby najbardziej oczekiwanych skutków prawnych. Kierując się zatem jedynie wykładnią językową doprowadzilibyśmy do przerwania pożądanej konstytucyjnie ciągłości władzy, gdyż w praktyce ustrojowej między potwierdzonym wyborem prezydenta-elekta a jego zaprzysiężeniem może upłynąć kilka dni, a w skrajnym przypadku nawet kilka tygodni. Kodeks wyborczy przyjęty w 2011 r. zastrzega bowiem, że prezydent wybrany w przedterminowych wyborach będących skutkiem opróżnienia urzędu głowy państwa winien złożyć swoją przysięgę wobec Zgromadzenia Narodowego w terminie 7 dni od ogłoszenia w Dzienniku Ustaw uchwały Sądu Najwyższego o stwierdzeniu ważności wyborów. ${ }^{23}$ Niedotrzymanie zaś tych terminów lub odmowa złożenia przysięgi przez prezydenta-elekta dodatkowo w każdym przypadku skutkuje koniecznością rozpisania nowych wyborów prezydenckich. A jak stanowi Konstytucja (art. 128 ust. 2), Marszałek Sejmu winien to uczynić nie później niż w czternastym dniu po opróżnieniu urzędu, wyznaczając datę wyborów w ciągu 60 dni od dnia zarządzenia wyborów. Stąd też wynika przewijający się w literaturze dylemat, czy na wypadek tak ekstremalnej sytuacji mamy faktycznie ustrojowo gwarantowaną ciągłość wykonywania obowiązków głowy państwa i czy nie należałoby wprowadzić stosownej zmiany regulacji konstytucyjnej celem uniknięcia rzeczywistego „wakatu” w czasowym wypełnianiu obowiązków prezydenckich? Póki to nie nastąpi ${ }^{24}$ zasadnym jest odejście od rygorystycznego stosowania wykładni językowej na rzecz wykładni celowościowej w zakresie interpretacji użytego nieopatrznie sformułowania „do czasu wyboru”, rozciągając na moment zaprzysiężenia. ${ }^{25} \mathrm{~W}$ końcu nadrzędną ratio legis art. 131 ust. 2 Konstytucji jest zachowanie permanentności działań głowy państwa, a już szczególnie jest to uzasadnione w sytuacji tak ekstraordynaryjnej jak opróżnienie urzędu Prezydenta Rzeczypospolitej. Zresztą do 1997 r.

23 Por. art. 291 ust. 3 ustawy z dnia 5 stycznia 2011 Kodeks wyborczy (Dz.U. z 2011 r. Nr 21, poz. 112).

2419 lutego 2010 r. wpłynął do laski marszałkowskiej stosowny projekt zmiany Konstytucji RP z inicjatywy posłów Klubu Parlamentarnego Platformy Obywatelskiej, który jednak zawisł po pierwszym czytaniu na etapie prac komisji nadzwyczajnej. Zob.: Druk sejmowy 2989, Sejm Rzeczypospolitej Polskiej VI kadencja, Warszawa 2010. Por.: http://orka.sejm.gov.pl/Druki6ka.nsf/0/5787955BEFAD18A0C125771300319A37/\$file/2989.pdf. (data dostępu: 30.06.2015 r.). Zob. również: Zmiany Konstytucji Rzeczypospolitej Polskiej w latach 1997-2011 w świetle projektów ustaw i oraz uchwalonych nowelizacji, Warszawa 2011, s. 12-13.

25 Podobnie stanowisko zajęli: M. Zubik, Gdy Marszalek Sejmu..., op. cit., s. 85; J. Ciapała, Prezydent w systemie ustrojowym Polski (1989-1997), Warszawa 1999, s. 126 oraz idem, Analiza prawna: Czy Polska ma p.o. Prezydenta, „Rzeczpospolita” z dnia 9 lipca 2010 r., s. C7; W. Skrzydło, Konstytucja Rzeczypospolitej Polskiej. Komentarz, Kraków 1998, s. 135; R. Mojak, Prezydent Rzeczypospolitej..., op. cit., s. 304; jak również: M. Domagalski, W. Wybranowski, Bez p.o. Prezydenta, „Rzeczpospolita” z dnia 8 lipca 2010 r., s. A3. 
ówcześnie obowiązujące regulacje konstytucyjne stanowiły wyraźnie, że w sytuacji opróżnienia urzędu prezydenckiego „do czasu objęcia urzędu przez nowego prezydenta" zastępować go będzie Marszałek Sejmu, również po upływie kadencji Sejmu. Zatem dzisiejsze brzmienie art. 131 ust. 2 Konstytucji należy potraktować jako nie do końca przemyślane w finalnym efekcie rozwiązanie, którego literalne stosowanie w praktyce doprowadziłoby do zerwania ciągłości władzy w państwie i stąd usprawiedliwioną wydaje się jego rozszerzona interpretacja. A i w tym kierunku podążyła praktyka ustrojowa z 2010 r. w uznaniu, że ustrojodawca nie mógł świadomie wprowadzić ,przerwy międzykadencyjnej” w sprawowaniu urzędu głowy państwa.

Pozostaje tylko zadać pytanie o zakres uprawnień podmiotu wykonującego pro tempore obowiązki Prezydenta RP w niepowszedniej sytuacji dla państwa, ale za to szczególnie wrażliwej ze względu na status głowy państwa, jej zakres kompetencyjny i wypełniane przezeń funkcje. Prezydent pozostaje bowiem w polskim porządku konstytucyjnym nie tylko istotnym ogniwem dualistycznej egzekutywy, lecz również organem realizującym koncept równoważenia władz w państwie. Celem gwarantowania ładu społeczno-politycznego w kraju władnym jest korzystać z pokaźnego zestawu środków służących mediacji, facylitacji czy wręcz formalnemu arbitrażowi politycznemu. W razie zakłócenia „właściwych” relacji między Sejmem a Radą Ministrów, pożądanych z punktu widzenia efektywności systemu rządów parlamentarnych, przyjmuje on na siebie rolę stabilizatora. Starając się doprowadzić do rozwiązania kryzysu politycznego, czuwa tym samym nad maksymalnie harmonijnym sprawowaniem władzy w kraju. W końcu on sam, zgodnie z art. 126 ust. 1 Konstytucji RP jest gwarantem ciągłości władzy państwowej (zatem nie tylko wykonawczej, ale również władzy ustawodawczej). Gwarantowanie ciągłości władzy przejawiać się przy tym winno chociażby poprzez jego działania inspiracyjne w stosunku tak do parlamentu, jak i do rządu. Ich przykładem może być możliwość zwoływania posiedzeń Rady Gabinetowej celem rozpatrzenia szczególnej wagi spraw państwowych lub też orędzie kierowane do parlamentu czy inicjatywa ustawodawcza. W przypadku naruszenia wartości chronionych konstytucyjnie wkraczanie prezydenta powinno z kolei przybrać postać działań już o charakterze hamującym, dobrym przykładem których jest zarówno weto ustawodawcze czy wnioskowanie do Trybunału Konstytucyjnego o przeprowadzenie prewencyjnej czy następczej kontroli konstytucyjności ustaw, jak i występowanie z wnioskiem do Sejmu o pociągnięcie premiera lub ministra do odpowiedzialności konstytucyjnej. Dodatkowo w przypadku braku większości parlamentarnej pozwalającej na względnie stabilną pracę Rady Ministrów, konstytucja zaopatrzyła go w uprawnienie do skrócenia kadencji parlamentu (art. 155 ust. 2). Reasumując, Prezydent RP dysponuje rozległym wachlarzem działań sugerujących, hamujących i rozstrzygających konflikty. Pamiętajmy o tym, że funkcje prezydenta jako gwaranta ciągłości władzy nie podlegają przy tym kontrasygnacie. Zatem czy ten sam zakres uprawnień przechodzi na osobę przejmującą tymczasowe wykonywanie jego obowiązków? Czy prezydent zawia- 
damiając Marszałka Sejmu, iż przejściowo nie będzie władnym sprawować swojego urzędu, może przekazać mu tylko część uprawnień, zachowując pozostałą ich część w swojej dyspozycji? Konstytucja odnosząc się ogólnie do tego zagadnienia stanowi, iż „osoba wykonująca obowiązki Prezydenta Rzeczypospolitej Polskiej nie może postanowić o skróceniu kadencji Sejmu". Z tego należy wnioskować, iż osoba ta przejmuje całokształt uprawnień głowy państwa, z wyraźnym wyłączeniem tylko jedynego wyjątku expressis verbis wskazanego w art. 131 ust. 4 ustawy zasadniczej. Dotyczy to również sytuacji, gdy przejmowanie zastępstwa ad interim następuje na podstawie prezydenckiego zawiadomienia. W przeciwnym razie (tj. w przypadku możliwości przejęcia jedynie „cząstkowego” zakresu uprawnień prezydenckich przez Marszałka Sejmu), przychylając się do stanowiska prezentowanego w doktrynie, ,taka sytuacja prowadziłaby do powstania swoistego dualizmu władzy, w ramach którego domena prezydencka uległaby tymczasowemu rozerwaniu na dwa ośrodki polityczne w państwie". ${ }^{26}$ Ponadto podejmowanych działań przez osobę czasowo przejmującej obowiązki głowy państwa winny też dotyczyć, na podobieństwo działań samego prezydenta, wszelkiego rodzaju ograniczenia w postaci wymogu kontrasygnaty, działania „na wniosek” czy „po zasięgnięciu opinii” wskazanego literą prawa podmiotu.

W doktrynie jednak zwraca się przede wszystkim uwagę, iż Konstytucja konsekwentnie posługuje się pojęciem ,tymczasowe wykonywanie obowiązków Prezydenta RP" przez podmiot do tego konstytucyjnie upoważniony. Nie ma zaś w żadnej prawnej regulacji mowy o jego zastępowaniu, nie używa się też terminu ,p.o. Prezydent RP” w stosunku do marszałka przejmującego jego obowiązki. Wielokrotnie już było podkreślane, iż bez względu na przesłanki (czy to natury trwałej, czy przemijającej) przejęcia przez marszałka wzmiankowanych obowiązków jest to zawsze sytuacja charakteryzująca się założoną „tymczasowością”. W przypadku opróżnienia urzędu nie dokańcza on bowiem kadencji prezydenta, lecz jedynie przyjmuje na siebie ciężar jego obowiązków w ogólnie pojętym interesie państwa do czasu pozyskania bezpośredniej legitymacji od narodu przez kolejnego nowo wybranego prezydenta. W sytuacji zaś przejściowej niemożności w sprawowaniu urzędu przez głowę państwa - jedynie do czasu ustania przeszkody tę niedyspozycyjność powodującą. Mamy zatem do czynienia z zastępstwem w wykonywaniu obowiązków przypisanych do danego urzędu, a nie zastępstwem konkretnej osoby dotychczas ten urząd sprawującej. Marszałek wchodzi zatem niejako w kompetencje prezydenckie w jego zastępstwie. Nie występuje tu żaden akt zaprzysiężenia, czy inna inauguracyjna forma uroczystego objęcia stanowiska. Formalnie nie jest nawet zobowiązanym zawiesić wykonywania mandatu deputowanego czy też przewodniczącego izby parlamentarnej. 
Co do zasady nie może on też odmówić przejęcia wzmiankowanych obowiązków, gdyż ,przechodzą" one na Marszałka Sejmu z mocy samego prawa w przypadku opróżnienie urzędu prezydenta lub przekazania mu przez urzędującą głowę państwa zawiadomienia o przejściowej niemożności sprawowania przezeń swojego urzędu. Konstytucja (art. 131 ust. 3) zastrzega jedynie, że jeżeli Marszałek Sejmu nie będzie mógł wykonywać zadań Prezydenta RP, obowiązki te przejmie Marszałek Senatu. Jest to dosyć enigmatyczne sformułowanie, które nie określa przesłanek, które mogłyby uniemożliwić przejęcie przez Marszałka Sejmu prezydenckich obowiązków. Przyjmuje się jednak, iż winny one występować obiektywnie i być na tyle doniosłe, by stanowiły wystarczające usprawiedliwienie przejęcia na siebie obowiązków prezydenckich przez Marszałka Senatu. ${ }^{27} \mathrm{Z}$ tych samych też tylko względów prezydent może dokonać bezpośredniego zawiadomienia Marszałka Senatu o przekazaniu tymczasowo uprawnień do wykonywania obowiązków głowy państwa. Należy jednak pamiętać, iż Konstytucja przyznaje wyraźną „palmę pierwszeństwa” w tym zakresie Marszałkowi Sejmu. Objęcie zastępstwa przez Marszałka Senatu wymaga bowiem łącznego wystąpienia przejściowej niemożności sprawowania urzędu przez prezydenta lub wręcz jego opróżnienia oraz niemożności wykonywania w tej sytuacji obowiązków prezydenckich przez Marszałka Sejmu. Stąd przyjęto w praktyce, że jeżeli zanika przeszkoda dotychczas uniemożliwiająca przejęcie przez Marszałka Sejmu obowiązków głowy państwa, Marszałek Senatu ustępuje mu pola. Efektem takiego podejścia była, dość zresztą kuriozalna w swoim przebiegu, sytuacja. Otóż po tragicznej śmierci prezydenta L. Kaczyńskiego mającej miejsce 10 kwietnia 2010 r., ex lege jego obowiązki tego dnia objął ówczesny Marszałek Sejmu B. Komorowski. Jedenaście dni później wyznaczona została data przedterminowych wyborów prezydenckich (na dzień 20 czerwca), w których B. Komorowski wystartował i odniósł wyborcze zwycięstwo. Jako nowo wybrany Prezydent RP, 4 lipca 2010 r. zrzekł się funkcji przewodniczącego Sejmu, co pociągnęło za sobą również zaistnienie sytuacji „wakatu” w zakresie tymczasowego wykonywania obowiązków prezydenckich. W tej sytuacji status osoby, na której spoczął ciężar zastąpienia głowy państwa w zakresie bieżącej realizacji jej zadań pozyskał Marszałek Senatu B. Borusewicz. Choć z drugiej strony było to nadzwyczaj krótkotrwałe zastępstwo, bowiem jeszcze tego samego dnia Sejm dokonał wyboru G. Schetyny na stanowisko Marszałka Sejmu i tym samym na powrót obowiązki „zastępcy prezydenta” przeszły w ręce przewodniczącego izby pierwszej parlamentu. ${ }^{28} \mathrm{Z}$ tego wynika, że praktyka ustrojowa

Może to być przykładowo wcześniejsze postawienie go w stan oskarżenia przed Trybunałem Stanu (z zarzutem naruszenia zasad nakreślonych art. 107 konstytucji) lub rezygnacja danej osoby z pełnienia funkcji Marszałka Sejmu, możliwość taką daje bowiem od 2009 r. art. 10b regulaminu Sejmu (w brzmieniu ustalonym przez art. 1 pkt 8 uchwały Sejmu z dnia 19 grudnia 2008 r. w sprawie zmiany regulaminu Sejmu RP, która weszła w życie z dniem 12 stycznia 2009 r. - M. P. 2009, nr 2, poz. 9). Do przesłanek tych natomiast, zdaniem P. Sarneckiego, nie możemy zaliczyć przyczyn o naturze politycznej czy subiektywnej niechęci. Por.: Nota do art. 131, op. cit., s. 4 . beda_kolejno.html; (data dostępu: 2.07.2015 r.); http://www.wprost.pl/ar/201152/Schetyna-bedzie-do-sierpnia- 
w przypadku zaistnienia potrzeby przejęcia tymczasowo kompetencji prezydenckich przez Marszałka Senatu, choć przepisy konstytucyjne żadną miarą tego wprost nie przesądzają, zrezygnowała z permanentnej realizacji uprawnień prezydenckich przez Marszałka Senatu w osobie B. Borusewicza do momentu aż zaprzysiężenia nowego prezydenta, lecz potraktowała niniejszą sytuację jedynie jako procedurę rezerwową na czas istnienia przeszkody w wykonywaniu obowiązków przez Marszałka Sejmu. Warto wspomnieć przy tym, iż Konstytucja nie przewiduje innych procedur awaryjnych na wypadek, gdyby żaden z marszałków nie mógł faktycznie wykonywać obowiązków głowy państwa. Choć jest to mało prawdopodobne, jednak jak się wydaje w takiej sytuacji koniecznym byłoby jak najszybsze podjęcie stosownych kroków celem objęcia stanowiska przewodniczącego którejś z izb parlamentarnych przez osobę władną w rzeczywistości przejąć niniejsze obowiązki. Ale patrząc $z$ drugiej strony, wzorem chociażby bliskich naszym rozwiązaniom konstytucyjnym Republiki Federalnej Niemiec i kilku innych państw europejskich, ${ }^{29}$ wartym zastanowienia może byłoby przyjęcie modelu $\mathrm{z}$ choćby pierwszeństwem przejmowania $p o$ tempore obowiązków prezydenckich właśnie przez Marszałka Senatu, ze względu na znacznie mniejszy stopień w stosunku do przewodniczącego Sejmu, uwikłania go w bieżącą działalność zarówno w wymiarze partyjnym, jak i ogólnopaństwowym.

Wartym podkreślenia jest również, iż marszałek korzystając z uprawnień prezydenckich, związane z tym obowiązki wykonywać musi osobiście i nie może ich scedowywać na wicemarszałków. Mogą oni jedynie wyręczać go w tej szczególnej sytuacji w realizacji zadań jako przewodniczącego izby, ale już nie mogą zastępować go w wykonywaniu tymczasowo obowiązków prezydenckich. Jest to o tyle istotne, że polskie regulacje nie przewidziały instytucji zawieszenia realizowania kompetencji przewodniczącego izby czy mandatu deputowanego w okresie przejęcia obowiązków prezydenckich. Pełni on zatem wyznaczone funkcje jednocześnie w ramach dwu władz. Generalnie nie jest to instytucja często spotykana we współczesnych rozwiązaniach konstytucyjnych, ale przykładowo konstytucje: Portugalii (art. 132), Estonii (art. 83), Litwy (art. 89) czy Węgier (art. 14 ust. 3) powierzając misję zastąpienia w wypełnianiu obowiązków głowy państwa przewodniczącemu parlamentu wyraźnie zastrzegły, że ich kompetencje jako deputowanego na ten czas ulegają zawieszeniu. Podobne rozwiązanie w swoim wymiarze przyjęła również

pelnil-obowiazki-prezydenta/ (data dostępu: 2.07.2015 r.).

Por. art. 57 Ustawy Zasadniczej RFN z dnia 23 maja 1949 r., zgodnie z którym „W razie przeszkody w pełnieniu obowiązków i przedwczesnego złożenia urzędu przez Prezydenta Federalnego jego uprawnienia wykonuje Przewodniczący Bundesratu". Na zastępstwo w podobnej sytuacji przez Przewodniczącego Senatu zdecydował się również ustrojodawca włoski (art. 86) oraz francuski (art. 7 - z dodatkowym zabezpieczeniem, że gdyby Przewodniczący Senatu nie mógł ich wykonywać, niniejsze obowiązki przeszłyby na rząd). Również w Rumunii, młodej demokracji opierającej podobnie jak Polska swój ustrój o parlamentarno-gabinetowy system rządów, zdecydowano się przyznać pierwszeństwo, przed liderem Izby Deputowanych przewodniczącemu Senatu w zastępowaniu prezydenta (art. 97) Zob.: Konstytucja Niemiec, Warszawa 2008, s. 62; Konstytucja Włoch, Warszawa 2004, s. 79; Konstytucja V Republiki Francuskiej, Warszawa 2011, s. 26; Konstytucja Rumunii, Warszawa 1996, s. 57. 
Konstytucja Republiki Macedonii (art. 82) stanowiąc, iż Przewodniczący Zgromadzenia sprawując $\mathrm{w}$ zastępstwie funkcje prezydenta, uczestniczy wprawdzie w pracach parlamentu, ale bez prawa podejmowania decyzji. ${ }^{30}$

Marszałek Sejmu lub Senatu wykonujący obowiązki prezydenta, o czym była wcześniej mowa, działa na tych samych zasadach i w tym samym zakresie - z wyłączeniem jedynie prawa do skrócenia kadencji parlamentu ${ }^{31}$ - co zastępowany organ państwa. I choć nie staje się prezydentem, to jednak przejmuje wszystkie jego atrybuty, zgodnie z zasadą ,,co nie jest zakazane, jest dozwolone”, tak z punktu widzenia prawa krajowego, jak i międzynarodowego (np. B. Komorowski w tym charakterze reprezentował przykładowo Rzeczpospolitą 9 maja 2010 r. w Moskwie na uroczystych obchodach 65-lecia zakończenia II wojny światowej). ,Tymczasowość” wykonywania niniejszych obowiązków każe jednak doktrynie postulować podejmowania się przezeń działań jedynie nie cierpiących zwłoki czy też nie wywołujących trwałych skutków. I co warto podkreślić, w tym zakresie istnieje pełna zgodność poglądów. ${ }^{32}$ J. Ciapała sugerował, iż już autorami znacznej części projektów konstytucyjnych wniesionych do Zgromadzenia Narodowego (tj. prezydenckiego, senackiego oraz poselskich zgłoszonych przez Sojusz Lewicy Demokratycznej oraz Porozumienie Centrum) kierowała intencja, iż „osoba zastępująca prezydenta powinna ograniczyć się do podejmowania tylko takich działań, które wynikają z konieczności podjęcia rozstrzygnięć w zakresie bieżących spraw państwowych. Chodzi tu tylko o takie działania, które są niezbędne i bez których niemożliwe jest normalne funkcjonowanie państwa". P. Tuleja oraz K. Wojtyczek uważają, iż osoba wykonująca obowiązki

30 Por.: Konstytucja Portugalii, Warszawa 2000, s. 99; Konstytucja Estonii, Warszawa 2000, s. 50; Konstytucja Litwy, Warszawa 2000, s. 53; Konstytucja Węgier, Warszawa 2012, s. 79; Konstytucja Macedonii, Warszawa 1999, s. 40 .

31 Choć jest to powszechne zastrzeżenie prawne występujące w większości europejskich rozwiązań konstytucyjnych, mające na uwadze uniemożliwienie dalszego pogłębienia i tak już niełatwej dla państwa sytuacji - to, odnosząc się do polskich uregulowań, zasadnym może być zadanie sobie pytania, czy osoba pełniąca obowiązki prezydenta, choć nie uprawniona do podejmowania decyzji o skróceniu kadencji Sejmu, mimo wszystko nie powinna móc skorzystać z tego uprawnienia w perspektywie braku wymaganej większości parlamentarnej władnej udzielić inwestytury Radzie Ministrów powołanej w ramach trzeciej procedury konstytucyjnej. O ile bowiem ograniczenie w zakresie podjęcia decyzji o skróceniu okresu pełnomocnictw Sejmu, w sytuacji niedotrzymania terminu przedłożenia do podpisu ustawy budżetowej (art. 225 konstytucji) jest w pełni uzasadnione, bo nawet w takich okolicznościach mamy zabezpieczoną nieprzerwaną możliwość prowadzenia przez rząd gospodarki finansowej państwa (por. art. 219 ust. 4 konstytucji), to w przypadku zaistnienia kryzysu politycznego opisanego uregulowaniem art. 155 ust. 1 konstytucji, brak możliwości reakcji w formie skrócenia kadencji Sejmu i rozpisania przedterminowych wyborów parlamentarnych pogłębiać będzie tylko poczucie zamętu spraw państwowych. Funkcjonowanie „rządu mniejszościowego” przy skrajnie rozbitej politycznie scenie parlamentarnej i dodatkowo w sytuacji braku w osobie prezydenta tzw. stabilizatora, na dłuższą metę będzie tylko pogłębiać społeczne poczucie kryzysu spraw państwowych, a nie taka była intencja ustanowienia niniejszego zakazu przez ustrojodawcę. Podobne wątpliwości zgłaszał M. Podsiadło, Odporność..., op. cit., s. 233.

32 Zob.: J. Ciapała, Prezydent..., op. cit., s. 127; P. Tuleja, Prawo konstytucyjne, Warszawa 1995, s. 201; K. Wojtyczek, Prezydent Rzeczypospolitej, (w:) Prawo konstytucyjne RP, P. Sarnecki (red.), Warszawa 1999, s. 276; M. Zubik, Gdy Marszalek Sejmu..., op. cit., s. 76; L. Garlicki Polskie prawo konstytucyjne. Zarys wykładu, cz. 2, Warszawa 1998, s. 51; P. Winczorek, Wyprowadzić państwo z traumy, Rzeczpospolita z dnia 12 kwietnia 2010 r., s. A21 (http://www.rp.pl/artykul/460122.html?print=tak\&p=0) (data dostęu: 5.07.2015 r.); Zastępstwo Prezydenta RP. Analiza obowiązujących przepisów na tle wydarzeń po 10 kwietnia 2010 r., E. Sadowska (red.), Kraków 2011, s. 22-23, http://prawo.gazetaprawna.pl/artykuly/412546,kto_zastapi_ofiary_katastrofy_w_smolensku_analiza_ konstytucyjna.html (data dostępu: 5.07.2015 r.). 
w zastępstwie prezydenta choć dysponuje takim samym zakresem kompetencji jak on, to jednak posiadając jedynie bardzo ograniczoną legitymację do sprawowania tej władzy i wynikającą jedynie z konieczności zachowania jej permanencji ,powinna ograniczyć się do podejmowania decyzji w sprawach nie cierpiących zwłoki, unikając rozstrzygnięć wywołujących nieodwracalne skutki na przyszłość”. M. Zubik dodawał, iż marszałek powinien korzystać z uprawnień prezydenckich w tej sytuacji „w sposób powściągliwy, uwzględniając jednak rozsądnie rozumiane wymogi konieczności funkcjonowania państwa". Podobne argumenty, tj. tymczasowość sytuacji oraz brak wyborczej legitymacji, skłoniły również L. Garlickiego do poparcia stanowiska, zgodnie z którym „Marszałek powinien ograniczyć swą aktywność do podejmowania czynności bieżących, chyba że zajdzie sytuacja nie cierpiąca zwłoki (np. dojdzie do upadku rządu)". Podobnej odpowiedzi na pytanie czy Marszałek Sejmu powinien bez samoograniczeń korzystać z uzyskanego na krótki czas dodatkowego ustrojowego statusu w sytuacji, jaka miała miejsce po 10 kwietnia 2010 r., kiedy to zginął prezydent L. Kaczyński udzielił P. Winczorek. Jego zdaniem „Marszałek Sejmu w roli tymczasowej głowy państwa powinien podejmować jedynie działania pilne lub konieczne z powodów prawnych lub faktycznych". Inne zaś, jego zdaniem winny poczekać aż do wyboru nowego prezydenta. Dodawał przy tym, iż nie chodzi tu o powinność w sensie prawnym, lecz raczej politycznym. Była to o tyle bezprecedensowa sytuacja, że wraz z prezydentem ówcześnie śmierć poniosło w katastrofie lotniczej kilkudziesięciu innych wysokich funkcjonariuszy państwa. Jednak, nawet w tak tragicznej w ludzkim wymiarze sytuacji, jaką była jednoczesna utrata tak dużej liczby wysokich funkcjonariuszy państwa, zdaniem G. Grabowskiej państwo polskie było na tyle zabezpieczone prawnie, że nie powinno to skutkować jego paraliżem. Obowiązujące przepisy przewidują bowiem odpowiednie procedury postępowania $\mathrm{w}$ takich sytuacjach i dokładnie wskazują kto będzie kierował daną instytucją do czasu wyboru nowego szefa, a także w jakim trybie wybór ten będzie przeprowadzany. Zdaniem profesor, marszałek w tego typu sytuacji choć wykonuje te same obowiązki, to winien korzystać z nich z umiarem i podejmować jedynie kroki nie cierpiące zwłoki ,dla dobra Polski i łagodzenia konfliktów”, a zatem w zaistniałej sytuacji - odnosząc się do wydarzeń z 2010 r. - „może dokończyć tylko to, co leży na biurku prezydenta Kaczyńskiego” i „nie powinien więc powoływać osób pełniących najważniejsze funkcje w państwie", choćby explicite w myśl art. 131. ust. 4 Konstytucji zastępujący pro tempore prezydenta nie mógł tylko postanowić o skróceniu kadencji Sejmu.

Praktyka jednak poszła w innym kierunku, bowiem w czteromiesięcznym okresie zastępowania przez marszałków w jego obowiązkach Prezydenta RP skorzystano praktycznie ze wszystkich przewidzianych dlań konstytucyjnych uprawnień. I o ile nie można mieć zastrzeżeń, że w tym okresie doszło do dokonania szeregu nominacji profesorskich czy sędziowskich, w tym powołania nowego Prezesa NSA w związku 
z upływem kadencji jego poprzednika, czy też podpisania 76 ustaw $^{33}$ oraz ratyfikacji 9 umów międzynarodowych, to już z wieloma mniej pilnymi decyzjami choćby nominacyjnymi zapewne można było się wstrzymać, zadość czyniąc postulatom doktryny o wstrzemięźliwość w tym zakresie i podejmowanie jedynie działań z zakresu bieżącego zarządu. ${ }^{34}$ Najwięcej kontrowersji w tym zakresie wzbudziła ówcześnie obsada stanowiska Prezesa Narodowego Banku Polskiego. Zarzucono bowiem marszałkowi B. Komorowskiemu (który 27 maja wyznaczył M. Belkę jako kandydata na to stanowisko celem powołania go przez Sejm), że wykorzystuje okazję, by zmienić układ sił w składzie kierownictwa NBP na korzyść partii, do której należy, w sytuacji gdy nie ma zagrożenia dla wydolnego działania tej instytucji do czasu wyłonienia pełnoprawnie legitymowanej w wyborach powszechnych głowy państwa. Również nominacja J. Michałowskiego na szefa Kancelarii Prezydenta RP w sytuacji niepotwierdzenia jeszcze śmierci L. Kaczyńskiego i osób towarzyszących, gdy bieżący zarząd instytucją zapewniał J. Sasin, wiceszef Kancelarii, podobnie jak sposób powołania dwóch członków Krajowej Rady Radiofonii i Telewizji były ówcześnie kwestionowane. Podjęto też w tym czasie wiele istotnych decyzji w zakresie uprawnień prezydenckich z obszaru bezpieczeństwa państwa i jego obronności, w tym dotyczących obsady kilku stanowisk w najwyższym dowództwie polskich Sił Zbrojnych. Ponadto dokonano kilkunastu powołań pełnomocnych przedstawicieli dyplomatycznych Rzeczypospolitej, mających reprezentować interesy kraju i jego obywateli na terenie innych państw.

Stąd kierowanie się poszanowaniem jedynie tradycji ustrojowej, patrząc z praktycznego punktu widzenia jest niewystarczającym argumentem do trzymania się sztywno raz przyjętej ,procedury awaryjnej” w sytuacji opróżnienia urzędu Prezydenta RP czy przejściowego „wakatu” w możliwości jego sprawowania. Może wzorem innych państw, wartym przemyślenia jest zmiana przyjętego mechanizmu w kierunku przejmowania stosownych uprawnień w zastępstwie prezydenta przez Prezesa Rady Ministrów lub rozdziału realizacji tych kompetencji między niego a przewodniczącego jednej izb parlamentu (i to najlepiej ze wskazaniem na Marszałka Senatu). Podobnego typu rozwiązania wprowadzono choćby w regulacjach

33 Najwięcej kontrowersji w zakresie wykorzystania kompetencji prezydenckich przez Marszałka Sejmu (wówczas w osobie B. Komorowskiego) wypełniającego obowiązki głowy państwa w zakresie ustawodawstwa wzbudziło podpisanie ustawy dotyczącej Instytutu Pamięci Narodowej, której zakwestionowanie przed śmiercią zapowiedział L. Kaczyński i którą to nowelizację zmarły w katastrofie Rzecznik Praw Obywatelskich J. Kochanowski zamierzał zaskarżyć do Trybunału Konstytucyjnego. Za: http://www.fronda.pl/a/naukowcy-apeluja-o-zawetowanie-nowelizacji-ustawy-o-ipn,6117.html (data dostępu: 12.07.2015 r.); http://www.rp.pl/artykul/463702.html?print=tak; http://wiadomosci.dziennik.pl/polityka/artykuly/116193,apeluja-o-zawetowanie-ustawy-o-ipn.html; (data dostępu: 12.07.2015 r.).

34 Szerzej na temat podjętych działań i decyzji przez osoby pełniące tymczasowo obowiązki głowy państwa w okresie od 10 kwietnia do 6 sierpnia 2010 r. zob.: http://www.prezydent.pl/kancelaria/ dzialalnosc-kancelarii/art,764, dzialania-marszalka-wykonujacego-obowiazki-prezydenta-rp-bronislawa-komorowskiego-w-okresie-10-04-8-07-2010-r-.html (data dostępu: 12.07.2015 r.); http://www.prezydent.pl/kancelaria/ dzialalnosc-kancelarii/art,764, dzialania-marszalka-wykonujacego-obowiazki-prezydenta-rp-bronislawa-komorowskiego-w-okresie-10-04-8-07-2010-r-.html (data dostępu: 12.07.2015 r.); M. Zubik, Gdy Marszalek Sejmu..., op. cit., s. 80-84; Zastępstwo Prezydenta RP. Analiza obowiązujących przepisów..., op. cit., s. 29-33. 
konstytucyjnych Finlandii (art. 59 - zastępuje premier lub jeżeli również premier nie może sprawować urzędu, minister piastujący funkcję zastępcy premiera); Austrii (art. 64 - w sytuacji przejściowej niemożności funkcję przejmuje Kanclerza Federalny; jeżeli zaś przeszkoda uniemożliwia sprawowanie urzędu prezydentowi powyżej 20 dni lub na stałe kompetencje przechodzą na stosowne kolegium składające się z przewodniczącego Rady Narodowej i jego zastępców), Czech (art. 66 - premier przejmuje obowiązki w sferze polityki zagranicznej i bezpieczeństwa państwa oraz wykonuje tradycyjne kompetencje głowy państwa, do spółki z przewodniczącym parlamentu, w zakresie spraw wewnętrznych), Słowacji (art. 105 - formalnie ciężar obowiązków bierze na siebie rząd, powierzający swojemu przewodniczącemu wykonywanie niektórych uprawnien prezydenckich obok przewodniczącego Rady Narodowej), Rosji (art. 92 ust. 3 - wyłącznie premier) czy Ukrainy (art. 112 - wyłącznie premier), ${ }^{35}$ a zastępstwo przez osoby związane $\mathrm{z}$ rządem oraz gabinet działający in gremio statystycznie jest drugim co do popularności wśród współczesnych państw europejskich, a do tego dochodzą jeszcze ciekawe rozwiązania zastępstwa podzielonego jak w przypadku Czech czy Słowacji. ${ }^{36}$ Byłoby to o tyle uzasadnione, iż w obecnym stanie prawnym w Polsce, gdzie struktura aparatu władzy państwowej oparta została o zasadę podziału władz, co do zasady wszystkie (z jednym tylko wyjątkiem) uprawnienia Prezydenta RP ,przechodzą” wyłącznie na najwyższego przedstawiciela władzy ustawodawczej, przez co instrument praktycznie traci sens polityczny. A w końcu obecna Konstytucja zasadniczo „misję” prowadzenia polityki tak wewnętrznej, jak i zagranicznej powierzyła Radzie Ministrów, przyjmując również w tym zakresie zasadę domniemania jej kompetencji (art. 146 ust. 2). Poza tym rząd i jego przewodniczący pod względem funkcjonalnym, będąc ogniwami władzy wykonawczej, są o wiele bliżsi prezydentowi niż przewodniczący izb parlamentarnych. Ostatecznie prezydent i gabinet winne są kooperować w zakresie wypełniania władzy wykonawczej i jak podkreśla R. Mojak „to w interesie egzekutywy powinno leżeć zachowanie ciągłości władzy państwowej". ${ }^{37}$ Stosunkowo też mniej wątpliwości, o których wcześniej była mowa, rodziłoby w praktyce przejęcie kompetencji prezydenckich przez urzędującego Prezesa Rady Ministrów i nie do przecenienia pozostaje również fakt, iż ewentualne działania podejmowane przezeń w tym za-

Por.: Konstytucja Finlandii, Warszawa 2003, s. 85; Konstytucja Austrii, Warszawa 2004, s. 89; Konstytucja Republiki Czeskiej, Warszawa 1994, s. 52; Konstytucja Rosji, Warszawa 2000, s. 67; Konstytucja Ukrainy, Warszawa 1999, s. 69; http://libr.sejm.gov.pl/tek01/txt/konst/slowacja2011.html\#mozTocld966513 (data dostępu: 12.07.2015 r.).

36 O ciekawe zestawienie w tym zakresie pokusił się P. Chybalski, W sprawie ewentualnych zmian Konstytucji RP w zakresie przepisów dotyczących zastępstwa Prezydenta RP w świetle podobnych rozwiązań prawnych funkcjonujących w innych państwach Unii Europejskiej, „Przegląd Sejmowy” 2011, nr 1 (102), s. 100-103. Zob. również: Zastępstwo Prezydenta RP. Analiza obowiązujących przepisów..., op. cit., s. 10-13; M.M. Wiszowaty, Problematyka niemożności pełnienia urzędu przez głowę państwa - sede plena, sede vacante i kwestia zastępstwa jako przykłady regulacji kryzysowych na gruncie polskiej i europejskich regulacji konstytucyjnych, (w:) J. Oniszczuk (red.), Normalność i kryzys - jedność czy różnorodność. Refleksje filozoficznoprawne i ekonomiczno-społeczne w ujęciu aksjologicznym, Warszawa 2010, s. 407-409.

37 R. Mojak, Instytucja prezydenta w okresie przekształceń ustrojowych, Lublin 1995, s. 182. 
kresie na bieżąco mogłyby podlegać weryfikacji parlamentarnej w ramach instytucji konstruktywnego wotum nieufności.

Propozycja ta jest również warta rozważenia chociażby w kontekście kontrowersji, jakie budzi w obecnym stanie prawnym podległość jurysdykcji Trybunału Stanu osoby Marszałka Sejmu (czy odpowiednio Marszałka Senatu) pro tempore realizującego obowiązki Prezydenta RP. Marszałek Sejmu od momentu przywrócenia w 1989 r. do polskiego porządku konstytucyjnego instytucji prezydenta jest konstytucyjnie legitymowanym do przejmowania tymczasowo obowiązków głowy państwa w razie opróżnienia urzędu prezydenta lub przejściowej niemożności jego sprawowania (por. art. 32e ust. 2 ustawy z dnia 7 kwietnia 1989 r. o zmianie Konstytucji PRL), ale dopiero ustawa o zmianie ustawy o Trybunale Stanu przyjęta w dniu 12 grudnia $1992 \mathrm{r}^{38}$ uregulowała kwestię jego odpowiedzialności przed Trybunałem Stanu w tym samym karno-konstytucyjnym zakresie co pełnoprawnie legitymowana głowa państwa wraz z zastosowaniem tożsamego co w przypadku prezydenta mechanizmu proceduralnego (por. art. 2 ust. 3 uTS w brzmieniu przyjętym art. 1 pkt 1 wzmiankowanej ustawy z 1992 r.). Z kolei dzięki art. 49 ust. 2 Małej Konstytucji z 1992 r. po raz pierwszy Marszałek Senatu, w zastępstwie przewodniczącego Sejmu, został wskazany jako podmiot przejmujący obowiązki prezydenta celem zapewnienia ciągłości jego władzy. I szczęśliwie art. 50 ust. 3 Małej Konstytucji w nawiązaniu do wzmiankowanej regulacji przesądził wówczas bezwzględnie o odpowiednim stosowaniu również w jego przypadku zasad prezydenckiej odpowiedzialności przed Trybunałem Stanu, w przeciwnym razie w przedziale kilkuletnim występowałaby luka prawna w tym względzie. Nowelizacja ustawy o Trybunale Stanu 1992 r. bowiem pomijała milczeniem tę kwestię, co należy potraktować jako rażący przejaw niedbalstwa prawodawcy ${ }^{39}$ Ustawa przedmiotowa dopiero bowiem ten wariant sytuacyjny przejęła wprost do swojego uregulowania w $2001 \mathrm{r}^{40}$ Ale również od jej przyjęcia dylemat budzi w literaturze kwestia samej odpowiedzialności zastępcy pro tempore.

W obecnym stanie prawnym objęcie działań marszałka (czy to Sejmu, czy Senatu) zastępującego prezydenta reżimem odpowiedzialności konstytucyjnej zrodziło u wielu przedstawicieli doktryny wątpliwości z racji wyłącznie ustawowej jej podstawy prawnej (tj. art. 2 ust. 3 uTS) który stanowi, iż zakres odpowiedzialności karno-konstytucyjnej Prezydenta RP przed Trybunałem Stanu oraz mechanizm proceduralny jej egzekwowania ,stosuje się odpowiednio do Marszałka Sejmu

38 Dz.U. z 1993 r. Nr 5, poz. 22.

39 Ustawodawca przeprowadzając $w$ tym przypadku nowelizację ustawy o Trybunale Stanu zdawał się bowiem „nie zauważyć” wejścia w życie 8 grudnia 1992 r. postanowień Ustawy konstytucyjnej z dnia 17 października 1992 r. o wzajemnych stosunkach między władzą ustawodawczą i wykonawczą Rzeczypospolitej Polskiej oraz o samorządzie terytorialnym (Dz.U. z 1992 r. Nr 84, poz. 426).

40 Por.: art. 2 ust. $3 \mathrm{w}$ brzmieniu przyjętym art. 1 pkt 1 ustawy z dnia 6 września 2001 r. o zmianie ustawy o Trybunale Stanu (Dz.U. z 2001 r. Nr 125, poz. 1372). W ciekawy sposób historię regulacji art. 2 ust. 3 uTS na tle zmian konstytucyjnych w Polsce po 1989 r. przedstawił M. Pach, Odpowiedzialność Marszalka Sejmu (Senatu) wykonującego obowiązki Prezydenta RP, „Przegląd Sejmowy” 2012, nr 2 (102), s. 41-48. 
i Marszałka Senatu, którzy tymczasowo wykonują obowiązki Prezydenta”. W piśmiennictwie naukowym powszechnie uznawany jest pogląd, iż ustawa zasadnicza z 1997 r. kreuje zamknięty katalog osób podlegających kognicji Trybunału Stanu. Art. 33b ust. 1 Konstytucji z 1952 r. przyjmował bowiem odmienną metodę unormowania stanowiąc jedynie, że „Trybunał Stanu może orzekać o odpowiedzialności osób zajmujących określone w ustawie najwyższe stanowiska państwowe za naruszenie Konstytucji i ustaw", ${ }^{41}$ pozostawiając tym samym ustawodawcy otwartą drogę do odpowiedniego uregulowania zakresu podmiotowego odpowiedzialności konstytucyjnej, jedynie z ograniczeniem jej do „osób zajmujących najwyższe stanowiska” w strukturze państwa. Stąd niektórzy autorzy przyjęli stosowne wyliczenie z art. 198 Konstytucji RP, jako wyraz bezsprzecznej eliminacji Marszałka Sejmu (czy Senatu) występującego w charakterze zastępującego w pełnieniu obowiązków głowy państwa $\mathrm{z}$ tego podmiotowego katalogu, bowiem ich zdaniem rozszerzająca wykładnia przepisów konstytucyjnych nie powinna mieć tu miejsca zgodnie z regułą clara non sunt interpretanda ${ }^{42} \mathrm{I}$ to pomimo iż $\mathrm{w}$ dotychczasowym uregulowaniu ustawowym (obowiązującym od czasu przywrócenia do porządku konstytucyjnego urzędu prezydenta w 1989 r.) formuła zastępowania i odpowiednio traktowanego zakresu odpowiedzialności Marszałka Sejmu wypełniającego w zastępstwie obowiązki prezydenckie była nieustająco obowiązującą. ${ }^{43}$ Inni podeszli do nowelizacyjnych działań ustawodawcy z dnia 6 września 2001 r. jako wręcz naruszających Konstytucję RP i opowiadając się za wyraźny zamknięciem możliwości egzekwowania odpowiedzialności „zastępców prezydenta” na analogicznych do niego zasadach, postulują ich uchylenie. ${ }^{44}$ Część autorów zaś odrzucenie możliwości zaliczenia osób „pełniących tymczasowo obowiązki Prezydenta RP" do zakresu kognicji Trybunału Stanu argumentowało jedynie utratą mocy obowiązującej art. 2 ust. 3 uTS jako pozostającego w sprzeczności z postanowieniami art. 198 Konstytucji RP z 1997 r. ${ }^{45}$ Choć z drugiej strony pamiętajmy, że obowiązującą jest zasada domniemania konstytucyj-

$41 \quad$ Na mocy art. 1 pkt 3 ustawy z dnia 26 marca 1982 r. o zmianie Konstytucji Rzeczypospolitej Ludowej (Dz.U. z 1982 r. Nr 11, poz. 83). Przepis ten wszedł w życie z dniem 6 kwietnia 1982 r. znajdując swoje miejsce w rozdziale 4 Konstytucji PRL z 1952 r.

Por. W. Skrzydło, Konstytucja..., op. cit., s. 212; D. Zrębiec. Zakres podmiotowy i przedmiotowy odpowiedzialności konstytucyjnej w nowej Konstytucji RP (wybrane zagadnienia), „Annales Universitatis Mariae Curie-Sklodowska", sectio G, vol. XLVI, 1999 , s. 218; J. Sobczak, Sądy i trybunały, (w:) W. Skrzydło (red.), Polskie prawo konstytucyjne, Lublin 2003, s. 409; M. Zubik, Organizacja wewnętrzna Sejmu Rzeczypospolitej Polskiej, Warszawa 2003, s. 59-61.

43 Por. art. 2 ust. 3 ustawy o Trybunale Stanu z 1982 r. w wersji ujednoliconego jej tekstu opublikowanego w dniu 7 kwietnia 1993 r. (Dz.U. z 1993 r. Nr 38, poz. 172).

44 Por.: D. Wajda, Uwagi o potrzebie reformy Trybunału Stanu, „Przegląd Sejmowy” 2008, nr 2(85), s. 120-121; B. Naleziński, Trybunał Stanu, (w:) P. Sarnecki (red.), Prawo konstytucyjne, Warszawa 1999, s. 362-363.

45 H. Groszyk, Uwagi o potrzebie i kierunkach zmian ustawowej regulacji Trybunału Stanu (w związku z art. 236 ust. 1 Konstytucji RP), (w:) Konstytucja, ustrój, system finansowy państwa. Księga pamiątkowa ku czci prof. Natalii Gajl, Warszawa 1999, s. 72; M. Granat, Normatywny model odpowiedzialności konstytucyjnej w praktyce, (w:) W. Skrzydło (red.), Sądy i trybunały w konstytucji i w praktyce, Warszawa 2005, s. 131; M. Zubik, Trybunały po dziesięciu latach obowiązywania Konstytucji III RP, „Przegląd Sejmowy” 2007, nr 4(81), s. 170; Idem, Trybunał Stanu - stan Trybunału (Słów kilka o polskim sądzie nad notablami), (w:) A Szmyt (red.), Trzecia władza. Sądy i trybunały w Polsce. Materiały Jubileuszowego L Ogólnopolskiego Zjazdu Katedr i Zakładów Prawa konstytucyjnego, Gdynia 24-26 kwietnia 2008 roku, Gdańsk 2008, s. 44-45. 
ności przepisu do momentu jego zakwestionowania przez Trybunał Konstytucyjny, a żaden uprawniony podmiot jak dotychczas (pomimo upływu już kilkunastu lat od jego wprowadzenia) nie zdecydował się na podjęcie stosownych kroków w tym kierunku. Jednocześnie jednak znaczna część autorów potraktowała regulację art. 2 ust. 3 uTS przyjętą w dniu 6 września 2001 r. jako działania mające na celu wyeliminowanie niedopatrzenia czy błędu ustrojodawcy, ${ }^{46}$ który wprawdzie w art. 198 pośród osób podległych jurysdykcji Trybunału Stanu wymieniał posłów i senatorów (odmiennie przy tym od pozostałych podmiotów określiwszy zakres przedmiotowy ich odpowiedzialności), ale już pominął milczeniem Marszałka Sejmu oraz Marszałka Senatu, którzy tymczasowo wykonują obowiązki Prezydenta RP. Oczywiście samą formułę sanacji przyjętych rozwiązań konstytucyjnych drogą ustawodawstwa zwykłego należy uznać za wadliwą, ale z drugiej strony analogiczny zakres kompetencyjny obydwu podmiotów rodzić powinien tożsamy zakres ich odpowiedzialności. ${ }^{47}$ W końcu ten sam ustrojodawca, zgodnie z art. 131 ust. 4 Konstytucji ustanowił, że zastępujący prezydenta Marszałek Sejmu (lub Senatu) dysponuje wszystkimi jego uprawnieniami z wyjątkiem prawa skrócenia kadencji Sejmu i nie zastrzegając przy tym, mimo odmiennych postulatów doktryny, żadnej powściągliwości czy umiaru w tym zakresie. Zatem pole aktywności zastępcy pro tempore (choć nie ma on bezpośredniej legitymacji społecznej do wypełniania tej funkcji) jest tak rozlegle co do zasady jak pełnoprawnej głowy państwa (tj. możliwość podejmowania licznych decyzji personalnych, promulgacja ustaw lub możliwość ich wetowania, ratyfikowanie umów międzynarodowych, wprowadzanie stanów nadzwyczajnych i wiele innych, wymiernie oddziaływujących tak na bieżące, jak i dalekosiężne sprawy państwa) i choć założeniem konstytucyjnym jest jedynie tymczasowość wypełniania tych obowiązków przez marszałka, to przy sprzyjających okolicznościach ów przejściowy charakter może przybrać rozległy wymiar czasowy. Same zaś dane statystyczne $\mathrm{z}$ praktycznych działań w okresie zastępstwa sede vacante przede wszystkim marszałka B. Komorowskiego, choć przy wydatnym też udziale marszałka G. Schetyny ukazały możliwą skalę ich aktywności w wymiarze raptem czteromiesięcznym, ${ }^{48}$ nie

46 P. Sarnecki, Prezydent Rzeczypospolitej Polskiej. Komentarz do przepisów, Warszawa 2000, s. 51; Idem, Nota do art. 145, (w:) Konstytucja Rzeczypospolitej Polskiej. Komentarz, t. I, L. Garlicki (red.), Warszawa 1999, s. 4; L. Garlicki, Polskie prawo konstytucyjne. Zarys wykładu, Warszawa 2003, s. 401; M. Kowalska, Organy władzy sądowniczej, (w:) Z. Szeliga (red.), Organy władzy publicznej świetle Konstytucji Rzeczypospolitej Polskiej 2 kwietnia 1997 roku, Lublin 2006, s. 192; W. Szyszkowski, Trybunał Stanu, (w:) Zbigniew Witkowski (red.), Prawo konstytucyjne, Toruń 2006, s. 546; K. Działocha, T. Zalasiński, Nota do art. 198, (w:) L. Garlicki (red.), Konstytucja Rzeczypospolitej Polskiej. Komentarz, t. V, Warszawa 2007, s. 13-14; S. Serafin, B. Szmulik, Organy ochrony prawnej, Warszawa 2007, s. 163; K. Prokop, Trybunał Stanu, (w:) M. Grzybowski (red.), Prawo konstytucyjne, Białystok 2008, s. 349; M. Zieliński, Trybunał Stanu jako organ sprawujący wymiar sprawiedliwości, (w:) M. Jabłoński, S. Jarosz-Żukowska (red.), Konstytucyjny model władzy sądowniczej w Polsce - wybrane problemy, Wrocław 2013, s. 206.

47 Podobne stanowisko, argumentując je wykładnią systemową w powiązaniu z wykładnią historyczną, zajął J. Zaleśny. Por.: Odpowiedzialność konstytucyjna w prawie polskim okresu transformacji ustrojowej, Toruń 2004, s. 174. Por.: dostępu: 18.07 .2015 r.) http://www.prezydent.pl/kancelaria/dzialalnosc-kancelarii/art,763,dzialania-marszalka 
wspominając już o kontrowersjach polityczno-prawnych, jakie część z podjętych czynności wzbudziła.

Może się zatem zdarzyć, że w tak masowej mimo wszystko skali działań podejmowanych w zastępstwie głowy państwa dojdzie do złamania litery prawa. Czy zatem mniej zasadnym jest pociągnięcie do odpowiedzialności konstytucyjnej zastępcy pro tempore działającego w tym zakresie bez społecznej legitymacji i co do zasady niepodlegającego również wyborczej kontroli następczej, lecz dysponującego w pełnym wymiarze $-\mathrm{z}$ jednym jedynym wyjątkiem - uprawnieniami bezpośrednio legitymowanego Prezydenta RP? W końcu intencją państwa prawa jest, aby podmioty znajdujące się w tożsamej sytuacji były podobnie traktowane. Logicznym zatem wydaje się przyjęcie rozwiązania, że marszałek wypełniający obowiązki prezydenta podlega podobnej odpowiedzialności przed Trybunałem Stanu, choć oczywiście jedynie w zakresie wykonywania tymczasowo obowiązków głowy państwa, a nie wszelkich funkcji realizowanych wówczas przez jego osobę (a więc również jako przewodniczący izby parlamentarnej). Sensownym zatem w tym przypadku byłoby zadośćuczynienie jedynie poglądom wyłączającym możliwość objęcia zastępującego prezydenta marszałka pełnym zakresem odpowiedzialności karnej przed Trybunałem Stanu na wzór samego prezydenta, ${ }^{49}$ a więc również za przestępstwa pospolite czy karnoskarbowe, których w tym czasie mógłby dopuścić się marszałek. W tym zakresie powinien bowiem jak każdy obywatel podlegać pod jurysdykcję sądownictwa powszechnego. Jedynie przypadek dopuszczenia się czynu wypełniającego znamiona zarówno przestępstwa, jak i deliktu konstytucyjnego, dawałby możliwość rozpatrzenia sprawy karnej przez Trybunał Stanu. Przyjęcie modelu zupełnej i wyłącznej właściwość Trybunału Stanu w sprawach karnych dotyczących przestępstw ewentualnie popełnionych przez głowę państwa jest bowiem oczywistą reakcją na szeroki zakres uprawnień kreacyjnych Prezydenta RP w stosunku do organów wymiaru sprawiedliwości oraz szczególnego szacunku dla samego urzędu głowy państwa. A jak już wspomniano, marszałek nie przejmuje urzędu jako takiego (nie dokańcza kadencji ustępującego prezydenta, nie składa przysięgi), a jedynie obowiązki z nim związane.

Na rzecz zachowania odpowiedzialności Marszałka Sejmu (Senatu) przemawia również fakt, że wypełniając obowiązki prezydenta staje się on podmiotem politycznym łączącym funkcje tak w ramach władzy ustawodawczej, jak i wykonawczej. Stąd też chociażby powinien płynąć nakaz objęcia go rygorem zwiększonej odpowiedzialności, gdyż większa liczba pozyskanych uprawnień winna implikować szerszy zakres odpowiedzialności w rezultacie ich realizacji. Dodatkowo warto za-

-wykonujacego-obowiazki-prezydenta-rp-grzegorza-schetyny-w-okresie-8-07-6-08-2010-r-.html (data dostępu: 18.07.2015 r.).

Por.: G. Koksanowicz, Prawnoustrojowa pozycja Marszałka Sejmu w świetle Konstytucji z 2 kwietnia 1997 r., „Przegląd Sejmowy” 2001, nr 3 (44), 19; H. Zięba-Załucka, Formy odpowiedzialności konstytucyjnej w Rzeczypospolitej Polskiej, (w:) S. Grabowska, R. Grabowski (red.), Formy odpowiedzialności konstytucyjnej w państwach europejskich, Torun 2010, s. 225. 
stanowić się, w kontekście stanowisk prezentowanych w piśmiennictwie negatywnie oceniających przyjęcie przez obecną ustawę zasadniczą zasady podległości posłów i senatorów jurysdykcji Trybunału Stanu i ich odpowiedzialności konstytucyjnej w ramach naruszeń regulacji antykorupcyjnych (art. 107), jako tradycyjnie zastrzeżonej dla członków przede wszystkim struktury władzy wykonawczej, iż zasadnym dla zaakcentowania i pogłębienia jego egzekutywnej roli w tym czasie może być przyjęcie formuły nakazującej zawieszenie wykonywania obowiązków przewodniczącego izby parlamentarnej czy nawet deputowanego (jak to ma miejsce w wielu państwach europejskich). Podsumowując, możemy powiedzieć jedynie, że dziś oczywiście argumenty przede wszystkim natury funkcjonalnej nakazują opowiedzieć się za utrzymaniem podległości Trybunałowi Stanu marszałków przejmujących w tymczasowe władanie uprawnienia Prezydenta RP. W końcu ile władzy, tyle odpowiedzialności. A faktyczne wyłączenie odpowiedzialności przed Trybunałem Stanu marszałków za czynności urzędowe wykonywane w zakresie obowiązków prezydenckich zrodziłoby jedynie niepożądaną w demokratycznym państwie prawa jednoczesną nieodpowiedzialność polityczną oraz prawną - a to moim zdaniem jest nie do zaakceptowania. I stąd koniecznym krokiem winno być przeprowadzenie procedury zmiany uregulowania art. 198 Konstytucji (jak również jej art. 131 ust. 2, w którym zwrot „do czasu wyboru” winien zostać zastąpionym ,do czasu objęcia urzędu" i tym samym wyeliminować formalnie występującą ,lukę międzykadencyjną"), aby rozwiać toczący się w doktrynie dyskurs ponad wszelką wątpliwość.

\section{BIBLIOGRAFIA}

Banaszak Bogusław. 2009. Konstytucja Rzeczypospolitej Polskiej. Komentarz. Warszawa: Wydawnictwo C.H. Beck.

Chybalski Piotr. 2011. W sprawie ewentualnych zmian Konstytucji RP w zakresie przepisów dotyczących zastępstwa Prezydenta RP w świetle podobnych rozwiązań prawnych funkcjonujących w innych państwach Unii Europejskiej. Przegląd Sejmowy 1 (102): 99-118.

Ciapała Jerzy. 1999. Prezydent w systemie ustrojowym Polski (1989-1997). Warszawa: Wydawnictwo Sejmowe.

Czeszejko-Sochacki Zdzisław, Leszek Garlicki, Janusz Trzciński. 1999. Komentarz do ustawy o Trybunale Konstytucyjnym. Warszawa: Wydawnictwo Sejmowe.

Działocha Kazimierz, Tomasz. Zalasiński. 2007. Nota do art. 198. W Konstytucja Rzeczypospolitej Polskiej. Komentarz, 1-16. Warszawa: Wydawnictwo Sejmowe.

Florczak-Wątor Monika. 2010. Konstytucyjne uregulowania problematyki zastępstwa prezydenta w Rzeczypospolitej polskiej i w państwach sąsiadujących. Przegląd Prawa Konstytucyjnego 2-3: 185- 207.

Garlicki Leszek. 1998. Polskie prawo konstytucyjne. Zarys wykładu. Cz. 2. Warszawa: Liber.

Garlicki Leszek. 2003. Polskie prawo konstytucyjne. Zarys wykładu. Warszawa: Liber. 
Granat Mirosław. 2005. Normatywny model odpowiedzialności konstytucyjnej w praktyce. W Sądy i trybunały w konstytucji i w praktyce, 124-142. Warszawa: Wydawnictwo Sejmowe.

Groszyk Henryk. 1999. Uwagi o potrzebie i kierunkach zmian ustawowej regulacji Trybunału Stanu (w związku z art. 236 ust. 1 Konstytucji RP). W Konstytucja, ustrój, system finansowy państwa. Księga pamiątkowa ku czci prof. Natalii Gajl, 65-78. Warszawa: Biuro Trybunału Konstytucyjnego.

Koksanowicz Grzegorz. 2001. Prawnoustrojowa pozycja Marszałka Sejmu w świetle Konstytucji z 2 kwietnia 1997 r. Przegląd Sejmowy 3 (44): 9-21.

Konstytucja Austrii. 2004. Warszawa: Wydawnictwo Sejmowe.

Konstytucja Bułgarii. 2012. Warszawa: Wydawnictwo Sejmowe.

Konstytucja Estonii. 2000. Warszawa: Wydawnictwo Sejmowe.

Konstytucja Finlandii. 2003. Warszawa: Wydawnictwo Sejmowe.

Konstytucja Litwy. 2000. Warszawa Wydawnictwo Sejmowe.

Konstytucja Niemiec. 2008. Warszawa: Wydawnictwo Sejmowe.

Konstytucja Macedonii. 1999. Warszawa: Wydawnictwo Sejmowe.

Konstytucja Portugalii. 2000. Warszawa: Wydawnictwo Sejmowe.

Konstytucja Republiki Czeskiej. 1994. Warszawa: Wydawnictwo Sejmowe.

Konstytucja Republiki Słowackiej.1993. Warszawa: Wydawnictwo Sejmowe.

Konstytucja Rosji. 2000. Warszawa: Wydawnictwo Sejmowe.

Konstytucja Rumunii. 1996. Warszawa: Wydawnictwo Sejmowe.

Konstytucja Ukrainy. 1999. Warszawa: Wydawnictwo Sejmowe.

Konstytucja Włoch. 2004. Warszawa: Wydawnictwo Sejmowe.

Konstytucja V Republiki Francuskiej. 2011. Warszawa: Wydawnictwo Sejmowe.

Konstytucja Węgier. 2012.Warszawa: Wydawnictwo Sejmowe.

Kowalska Monika. 2006. Organy kontroli państwowej i ochrony prawa. W: Organy władzy publicznej świetle Konstytucji Rzeczypospolitej Polskiej 2 kwietnia 1997 roku, 147-210. Lublin: Wydawnictwo UMCS.

Mojak Ryszard. 1995. Instytucja Prezydenta w okresie przekształceń ustrojowych. Lublin: Wydawnictwo UMCS.

Mojak Ryszard. 2003. Prezydent Rzeczypospolitej Polskiej, 288-324. W Polskie prawo konstytucyjne. Lublin: Wydawnictwo Verba.

Naleziński Bogumił. 1999. Trybunał Stanu. W Prawo konstytucyjne. Warszawa: Wydawnictwo C.H. Beck.

Olechno Artur, 2008. Prezydent Rzeczypospolitej Polskiej, 242-262. W Prawo konstytucyjne. Białystok: Wydawnictwo Temida 2.

Pach Maciej. 2012. Odpowiedzialność Marszalka Sejmu (Senatu) wykonującego obowiązki Prezydenta RP. Przegląd Sejmowy 2 (102): 35-56. 
Pastuszko Grzegorz. 2011. Marszałek Sejmu jako osoba wykonująca tymczasowo obowiązki prezydenta RP - dylematy konstytucyjne, Przegląd Prawa Konstytucyjnego 1: 83-107.

Podsiadło Michał. 2013. Odporność polskiego ustroju na „sytuacje awaryjne. W Konstytucja Rzeczypospolitej Polskiej w pierwszych dekadach XXI wieku wobec wyzwań politycznych, gospodarczych, technologicznych i społecznych, 231-238. Warszawa: Wydawnictwo Trybunału Konstytucyjnego.

Prokop Krzysztof. 2008. Trybunał Stanu. W Prawo konstytucyjne, 345-356. Białystok: Wydawnictwo Temida 2.

Sarnecki Paweł. 1999. Nota do art. 131. W Konstytucja Rzeczypospolitej Polskiej. Komentarz, 1-4. Warszawa: Wydawnictwo Sejmowe.

Sarnecki Paweł. 1999. Nota do art. 145. W Konstytucja Rzeczypospolitej Polskiej. Komentarz, 1-4. Warszawa: Wydawnictwo Sejmowe.

Sarnecki Paweł. 2000. Prezydent Rzeczypospolitej Polskiej. Komentarz do przepisów. Kraków: Zakamycze.

Serafin Sławomir, Bogumił Szmulik. 2007. Organy ochrony prawnej. Warszawa: Wydawnictwo C.H. Beck.

Skrzydło Wiesław. 1998. Konstytucja Rzeczypospolitej Polskiej. Komentarz. Kraków: Zakamycze.

Sobczak Jacek. 2003. Sądy i trybunały. W Polskie prawo konstytucyjne, 371-413. Lublin: Wydawnictwo Verba.

Szyszkowski Wacław. 2006. Trybunał Stanu. W Prawo konstytucyjne, 535-562. TNOIK Toruń.

Tuleja Piotr. 1995. Prawo konstytucyjne. Warszawa: Wydawnictwo C.H. Beck.

Wajda Dominik. 2008. Uwagi o potrzebie reformy Trybunału Stanu. Przegląd Sejmowy 2 (85): 113-133.

Winczorek Piotr. 2000. Komentarz do Konstytucji Rzeczypospolitej Polskiej z dnia 2 kwietnia 1997 r. Warszawa: Liber.

Wiszowaty Marcin Michał. 2010. Problematyka niemożności pełnienia urzędu przez głowę państwa sede plena, sede vacante i kwestia zastępstwa jako przykłady regulacji kryzysowych na gruncie polskiej i europejskich regulacji konstytucyjnych. W Normalność i kryzys - jedność czy różnorodność. Refleksje filozoficznoprawne i ekonomiczno-społeczne w ujęciu aksjologicznym. Warszawa: Szkoła Główna Handlowa - Oficyna Wydawnicza.

Wojtyczek Krzysztof. 1999. Prezydent Rzeczypospolitej. W Prawo konstytucyjne RP, 401-421. Warszawa: Wydawnictwo C.H. Beck.

Zaleśny Jacek. 2004. Odpowiedzialność konstytucyjna w prawie polskim okresu transformacji ustrojowej. Toruń: Wydawnictwo Adam Marszałek.

Zastępstwo Prezydenta RP. Analiza obowiązujących przepisów na tle wydarzeń po 10 kwietnia 2010 r. 2011. Kraków.

Zieliński Michał. 2013. Trybunał Stanu jako organ sprawujący wymiar sprawiedliwości. W Konstytucyjny model władzy sądowniczej w Polsce - wybrane problemy, 197-216. Wydawnictwo Uniwersytetu Wrocławskiego. 
Zięba-Załucka Halina. 2010. Formy odpowiedzialności konstytucyjnej w Rzeczypospolitej Polskiej. W: Formy odpowiedzialności konstytucyjnej w państwach europejskich, 218-238. Toruń: Wydawnictwo Adam Marszałek.

Zrębiec Dariusz. 1999. Zakres podmiotowy i przedmiotowy odpowiedzialności konstytucyjnej w nowej Konstytucji RP (wybrane zagadnienia). Annales UMCS. sectio G. vol. XLVI: 205-233.

Zubik Marek. 2010. Gdy Marszałek Sejmu jest pierwszą osobą w państwie czyli polskie interregnum. Przegląd Sejmowy 5 (100): 71-89.

Zubik Marek. 2003. Organizacja wewnętrzna Sejmu Rzeczypospolitej Polskiej. Warszawa: Wydawnictwo Sejmowe.

Zubik Marek. 2008. Trybunał Stanu - stan Trybunału (Słów kilka o polskim sądzie nad notablami.) W: Trzecia władza. Sądy i trybunały w Polsce. Materiały Jubileuszowego L Ogólnopolskiego Zjazdu Katedr i Zakładów Prawa konstytucyjnego. Gdynia 24-26 kwietnia 2008 roku, 41-58. Wydawnictwo Uniwersytetu Gdańskiego.

Zubik Marek. 2007. Trybunały po dziesięciu latach obowiązywania Konstytucji III RP, Przegląd Sejmowy 4 (81): 151-173.

Zmiany Konstytucji Rzeczypospolitej Polskiej w latach 1997-2011 w świetle projektów ustaw i oraz uchwalonych nowelizacji. 2011. Warszawa: Kancelaria Senatu Biuro Analiz i Dokumentacji. 


\section{THE LAW FACTOR OF REPLACEMENT OF THE POLISH PRESIDENT}

One of the fundamental rules in every contemporary democratic country, is maintaining continuity of the constitutional functioning of the key organs of state. Regulations enacted under the Polish Constitution of 1977, recognizes this rule and provides for it. In 1989, the presidential office was restored in Poland and its incumbent became the head of state. However, in the Polish political system there is no tradition of appointing a deputy-president. That is why it is necessary to regulate the issue of a replacement should the elected president become unable to fulfill the duties of office. In such event it is the Speaker of the Sejm who takes over the presidential duties. In extraordinary circumstances, this mechanism guarantees continuity in the functioning of the office of the Polish head of state.

Keywords: The Speaker of the Parliament, The President, contemporary replacement

Słowa kluczowe: Marszałek Sejmu, Prezydent RP, tymczasowe zastępstwo 